\title{
Hvad kaldte folk til Sønderjylland?
}

\author{
Det Sønderjyske Ministeriums administration af \\ læreransøgninger 1919-20
}

\section{af Erik Nørr}

Skolen indtager en vigtig plads $\mathrm{i}$ historien om Genforeningen. Samtlige skoleembeder i landsdelen skulle nybesættes, og fra årsskiftet 1918-19 strømmede ansøgningerne til de mange forventede stillinger ind. Arkivar, dr.phil. Erik Nørr har undersøgt de flere hundrede ansøgninger, der blev indsendt til Det Midlertidige Ministerium for Sønderjyske Anliggender. På denne baggrund fortælles om ministeriets og minister H.P. Hanssens rolle i en vigtig side af Genforeningens forberedelse.

Ved enhver grænseændring kommer spørgsmålet om embedsbesættelserne i fokus. Kan de hidtil ansatte fortsætte, eller må de erstattes af mere loyale folk? Ønsker de gamle embedsindehavere selv at fortsætte under de nye forhold og eventuelt aflægge ny embedsed? Hvilke sproglige krav skal der stilles til de folk, der forbliver i embedet? Er det klogt for de nye magthavere udelukkende at ansætte folk fra det øvrige land, eller bør man satse på at beholde flest muligt af dem, der har kendskab til de lokale nationalitetsforhold og så til gengæld risikere at få folk, der har en lidt blakket national fortid?

I Det Midlertidige Ministerium for Sønderjyske Anliggenders arkiv er der bevaret fire pakker med andragender om ansættelse i Sønderjylland efter Genforeningen. Desuden ligger der blandt ministeriets journalsager et støre antal stillingsansøgninger af tilsvarende art. ${ }^{1}$ De fleste ansøgninger drejede sig om ansættelse inden for skolevæsenet, postvæsenet, statsbanerne og toldvæsenet, men der var også henvendelser fra folk, der ønskede stilling inden for politiet, eller som ville overtage en lotterikollektion. En del ansøgninger var ikke så specifikke; man søgte blot arbejde i Sønderjylland. I det hele taget er det karakteristisk for de fleste ansøgninger, at de ikke er affødt af opslag af bestemte stillinger, men indsendt med den hensigt at fortælle myndighederne, at man er interesseret $i$ et job $i$ de genforenede landsdele.

Ikke alle stillinger var lige omstridte. F.eks. kunne poster inden for etaterne uden problemer tildeles folk, der havde erfaring inden for det pågxldende område, når de blot havde så gode danskkundskaber, at de nogenlunde kunne 


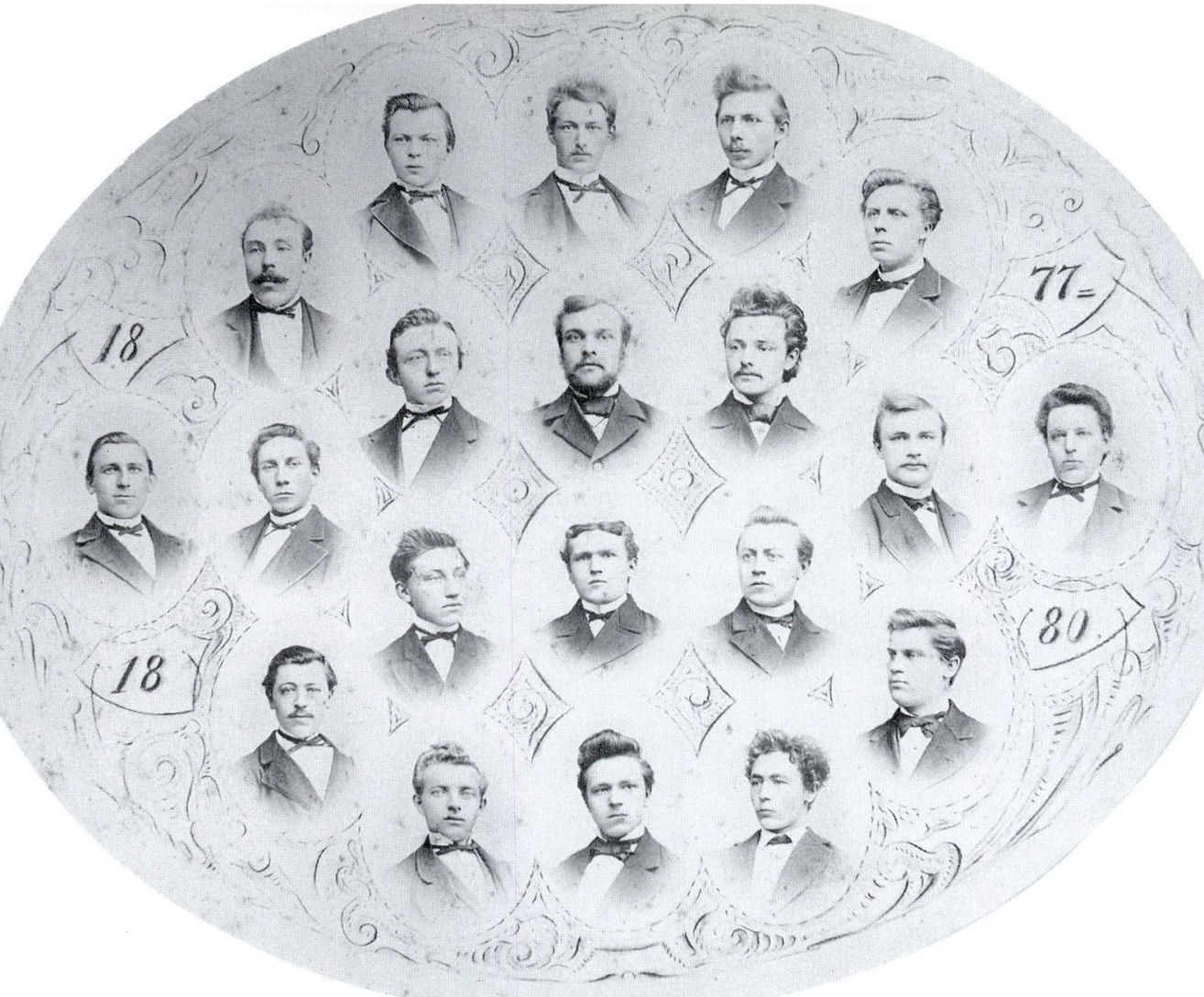

I en lang periode efter 1864 var der danskkyndige blandt de sonderjyske larere. Indtil 1884 fandtes der en dansksproget afdeling ved Tonder Seminarium. Derefter var seminariet et udpraget tysksindet sted, som mange dansksindede larerkandidater undgik. Billedet viser dimittenderne fra den dansksprogede afdeling 1880. Foto: Institut for snderjysk Lokalhistorie.

klare sig. Tysksindede kunne også komme i betragtning, men de måtte ikke have opført sig bevidst provokerende over for dansksindede. Anderledes med lærerstillinger.

Skolen var blevet en central brik i nationalitetskampen. Både efter Treårskrigen med de danske sprogreskripter og i preussertiden efter 1864 havde holdningen været, at den, der herskede over skolen, havde overtaget nationalt. Efter 1864 blev en række lærere især i købstæderne udskiftet, medens de fleste lærere på landet fortsatte. Seminariet i Tønder havde indtil 1884 en dansksproget afdeling. Overgangen fra dansk til tysk undervisning i Nordslesvig foregik derfor ikke brat, endnu i mange år efter 1864 var en stor del af lærerne danskuddannede. ${ }^{2}$ Den tyske skolepolitik blev væsentligt skærpet med sprogforordningen af 18/12-1888. Resultatet heraf blev en fortyskning af det offentlige 
skolevæsen og af lærerkorpset, men samtidig førte det til en vækkelse af den danske nationalitetsbevægelse. ${ }^{3}$

Formålet med denne artikel er for det første på baggrund af de indsendte andragender at belyse, hvorfor så mange søgte ansættelse i skolevæsenet i Sønderjylland efter Genforeningen: hvorfra de kom, hvilke forudsæetninger de havde, hvorhen de ønskede at komme, deres sproglige og nationale baggrund, med hvilke motiver de søgte, og hvad de gjorde for at komme i betragtning. For det andet skal artiklen belyse Det Midlertidige Ministerium for Sønderjyske Anliggenders administration af ansættelserne. Selv om H.P. Hanssens ministerium havde en central plads midt $\mathrm{i}$ brændpunktet i 1919-20, har ingen historiker hidtil beskæftiget sig med ministeriet i praksis.

\section{Medens man venter på Versailles}

I tiden fra våbenstilstanden i november 1918 og den efterfølgende rejsning af genforeningskravet, og indtil Versaillestraktaten blev vedtaget den 28.juni 1919 , befandt Sønderjylland sig administrativt set i noget af et vadested. Stillingsansættelser kunne ikke foregå som hidtil, da det var usikkert, hvor stort et landområde der ville blive afstået, og i hvilket omfang de hidtidige embedsmænd kunne fortsætte. På skoleområdet, som der udelukkende skal fokuseres på $\mathrm{i}$ denne artikel, fortsatte hovedparten af de hidtil ansatte lærere i første omgang i deres embede, men der opstod snart en række ubesatte stillinger. En del lærere var faldet $\mathrm{i}$ krigen, og andre søgte sydpå, da de enten havde markeret sig aktivt på den tyske side eller ikke følte sig sprogligt kompetente til at undervise på dansk. Endnu var der ingen myndighed, der kunne tage hånd om sagen. De rigsdanske ministerier havde ingen kompetence, og i Sønderjylland måtte man afvente fredstraktaten.

Imidlertid blev der i dette vakuum dannet nogle udvalg, der fik betydning for lærerspørgsmålet i overgangstiden. Den 23/12-1918 nedsatte Statsministeriet "Det Sønderjyske Udvalg" (også kaldet Det Slesvigske Udvalg). Udvalget, som bestod af kabinetssekretær A. Krieger og fuldmægtig Martin Hammerich, skulle besvare forespørgsler fra Nordslesvig og i det hele taget følge genforeningsprocessen. ${ }^{4}$ I Sønderjylland nedsatte Vælgerforeningen allerede i november 1918 et skoleudvalg, hvis medlemmer i høj grad havde tilknytning til Sønderjysk Skoleforening. Udvalgets formand og sekretær blev gårdejer H. Jefsen Christensen og Anders Lebeck, der var henholdsvis formand og kasserer $i$ Skoleforeningen. Udvalgets opgave var at udarbejde retningslinier for den sønderjyske folkeskoles overgang fra tysk til dansk lovgivning. ${ }^{5}$ 
I løbet af de første måneder af 1919 begyndte de første henvendelser fra lærere og lærerinder i Kongeriget at strømme ind til »Det Sønderjyske Udvalg« og til »Skoleudvalget«. I første omgang blev ansøgningerne blot henlagt. For som H.P.Hanssen skrev til en præst på Djursland, der ønskede at blive lærer i Sønderjylland og derfor havde henvendt sig direkte til ham: Der bliver "god Brug for Lærere hernede. Deres Brev vil blive rette Vedkommende forelagt, og De vil saa høre nærmere ${ }^{6}{ }^{6}$ Ingen vidste blot endnu, hvem rette vedkommende myndighed var.

Interessen for det sønderjyske skolevæsen voksede. Antallet af annoncer i dagbladene og i Danmarks Lærerforenings organ »Folkeskolen« efter lærere og lærerinder $\mathrm{i}$ overgangstiden blev flere og flere, og der blev skrevet artikler om skolen i Sønderjylland, ${ }^{7}$ ligesom emnet blev drøftet på flere skolemøder i Pinsen 1919.8

Den kaotiske situation skabte bekymring både i sønderjyske og rigsdanske kredse. Var det kun de skoler, hvor der af en eller anden grund var vakance, der kunne skaffe sig en dansk lærer, eller kunne også andre skoler skifte lærer, medens det var muligt? Hvor mange lærere kunne i det hele taget tænkes at ville drage sydpå efter Genforeningen, og hvordan kunne man få fat $\mathrm{i}$ egnede folk? Det sidste spørgsmål var yderst relevant. Som så mange gange både før og siden i skolehistorien passede lærerudbud og -efterspørgsel ikke til hinanden. ${ }^{9}$ I 1917-18 havde man nedlagt flere seminarier, og tilgangen til de øvrige var stærkt vigende, så kandidattallet ikke kunne klare behovet for nye lærere. ${ }^{10}$ Når lærerne kunne få faste job i Danmark, var der så nogen, der ville flytte ned til det uvisse syd for den hidtidige grænse?

For at få et overblik over, hvor mange lærere og lærerinder, der havde planer om at melde sig til skolearbejdet i Sønderjylland, og for at sikre sig, at kvalite-

\section{Vi soger \\ en Dansk Lreper}

nu ved Genforeningen til vor Eenklasses Skole her i Kase.

Skolen med Beboelse er ny og stor og rummelig. Ca. 50 Bern. Befolkningen alle Dansktalende og kun faa Hjemmetyskere. Den nuværende Lærer har været her over $20 \mathrm{Aar}$, men rejser, da han er Tysk. Mulige Ansegere maa melde sig senest 30 . Oktbr. til

Hans Petersen, sen., Skoleforstander, Kase pr. Hjortkjær, Senderjylland.

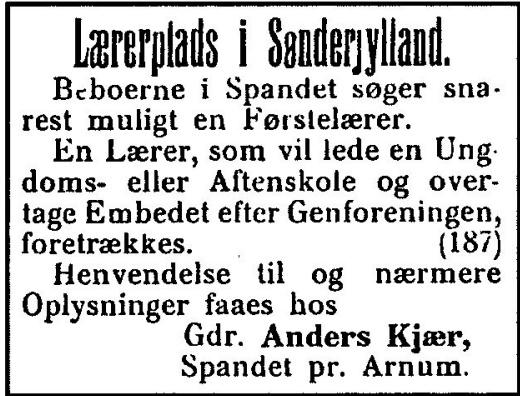

Larersporgsmálet $i$ Sonderjylland blev akut $i$ 1919, da en rakke skoler stod uden larer. De gengivne annoncer fra Danmarks Larerforenings blad "Folkeskolen" $\mathrm{nr} .44$ 30/10-1919 viser, at flere sonderjyske skoler sogte at sikre sig larere fra Danmark. 
ten af de danske lærere blev høj, opfordrede Vælgerforeningens skoleudvalg i begyndelsen af juni $1919 \mathrm{i}$ aviser og skoleblade interesserede til at indsende en "ikke-bindende" meddelelse herom. ${ }^{11}$ Tilkendegivelserne skulle sendes til højskoleforstander Jacob Appel, Askov, der fungerede som skoleudvalgets rådgiver, og som snart blev udset til at være skoledirektør for de sønderjyske landsdele i overgangstiden. Jacob Appel var desuden medlem af den i februar 1919 nedsatte skolekommission. ${ }^{12}$

I løbet af juni måned og $\mathrm{i}$ begyndelsen af juli modtog Jacob Appel $\mathrm{i}$ alt $\mathbf{7 7 3}$ henvendelser fra kongerigske lærere og lærerinder. ${ }^{13}$ De stammede fra hele landet. De fleste var kortfattede breve om, at vedkommende »agter at søge Embede i Sønderjylland efter Genforeningen «. Men en del var regulære ansøgninger med eksamensbeviser og anbefalinger. Af nogle ansøgninger fremgår det, at Appel har haft en del rend af folk i Askov i den anledning. Flere henviser til, at de har været tidligere elev på Askov, eller til, at de har grundtvigske sympatier eller været på højskoleophold. Appel må være blevet helt overvældet, for i Folkeskolen for den 3.juli måtte han fortælle de mange ansøgere, at det ikke var meningen, at de skulle indsende regulære ansøgninger, og at de ikke kunne forvente noget svar fra ham på spørgsmål om embederne $\mathrm{i}$ Sønderjylland. Lærerembederne ville til sin tid blive slået op. ${ }^{14}$ Snart skulle de utålmodige lærere få et nyt sted at indsende andragender til og søge oplysninger hos.

\section{Bomben i Folketinget}

Den 25. juni 1919 faldt der en »bombe« i Folketinget. Det var virkelig en sensation, der kom totalt overraskende for oppositionen, da statsminister C.Th. Zahle kunne meddele, at H.P. Hanssen var optaget i det radikale ministerium som midlertidig minister for sønderjyske anliggender. Det midlertidige lå $\mathrm{i}$, at ministeriet atter skulle nedlægges ved Genforeningen. De politiske følger af H.P.Hanssens udnævnelse er fyldigt behandlet af Troels Fink. ${ }^{15}$ Her skal det udelukkende dreje sig om de administrative konsekvenser af det nye ministeriums oprettelse.

Ministeriets hovedopgave var at varetage de særlige hensyn, der skulle tages som følge af en eventuel indlemmelse af dele af Sønderjylland i Danmark. Fagministerierne skulle høre Det Sønderjyske Ministerium om alle spørgsmål vedr. Sønderjylland. ${ }^{16}$ Selv om ministerudnævnelsen vakte furore, tillod Rigsdagen uden videre, at der blev oprettet et kontorchefembede i det nye ministerium. ${ }^{17}$ Embedet blev besat med fuldmægtig Martin Hammerich, som hidtil havde været sekretær i det nu nedlagte Sønderjyske Udvalg i Statsministeriet. 


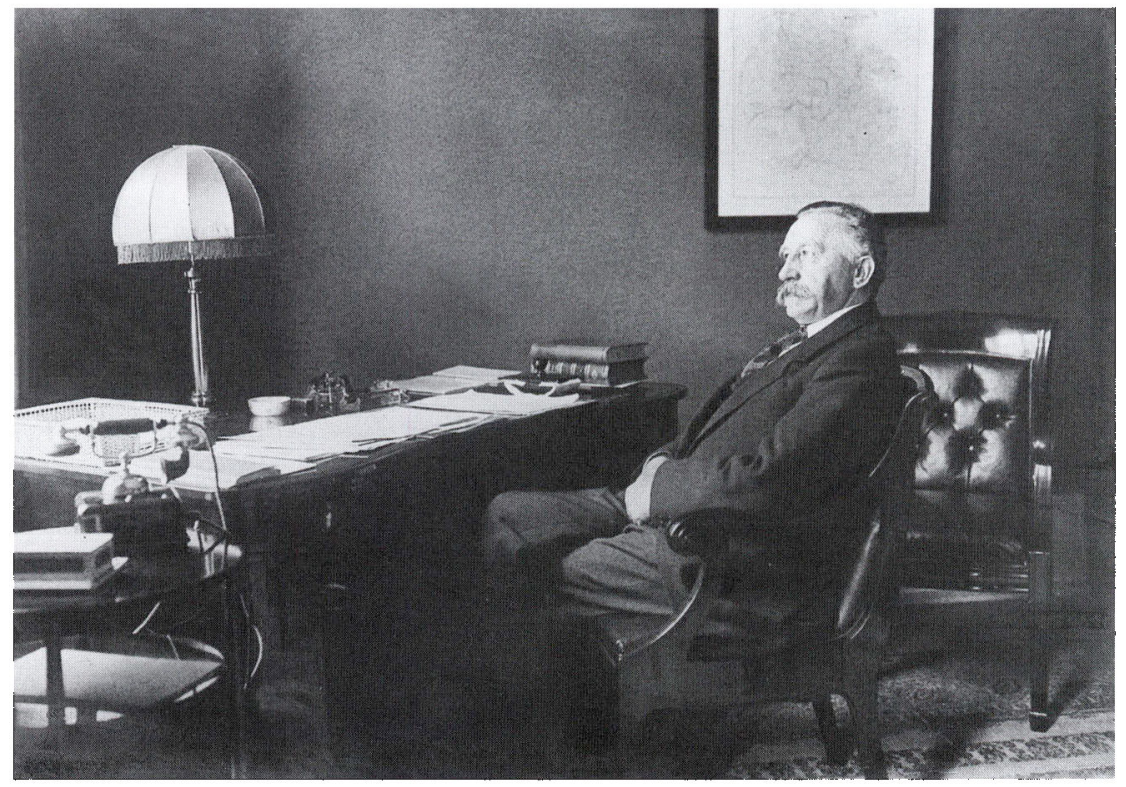

Det Sonderjyske Ministerium fik bopal i Niels Juels Gade 3, ikke langt fra Slotsholmen. Billedet af H.P. Hanssen på sit ministerkontor er fra 1919. Som eneste udsmykning på vaggen ses et kort over hele hertugdommet Slesvig. Foto: Institut for sonderjysk Lokalhistorie.

Han havde et godt kendskab til sønderjyske forhold og havde kendt H.P. Hanssen i mange år. I den følgende tid blev ministeriet bemandet med en fuldmægtig, et par sekretærer og et antal kvindelige kontormedarbejdere. ${ }^{18}$ For skoleadministrationen var det vigtigste navn ud over Hammerich, fuldmægtig Oluf Skjerbæk. Senere under genforeningsprocessen oprettede ministeriet kontorer i Aabenraa og Flensborg.

\section{Det Sønderjyske Ministerium finder sin plads}

Da Versaillesfredens ratifikation og Genforeningen trak ud, blev der i stigende grad behov for en ordning, så ledige sønderjyske embeder kunne blive besat på en rimelig måde. Både højskoleforstander Jacob Appel og Skoleudvalgets formand, H. Jefsen Christensen var optaget af, hvordan man kunne undgå, at Sønderjylland blev oversvømmet af en række til opgaven uegnede folk nordfra, som man så ikke senere kunne komme af med igen. Dette førte som nævnt til, at næsten 800 lærere og lærerinder indsendte en tilkendegivelse af, at de stod parat til at tage til Sønderjylland. 
Spørgsmålet var nu, hvad man skulle foretage sig med alle disse henvendelser. I første omgang anmodede Det Sønderjyske Ministerium Appel om at sende dem til ministeriet, hvilket dog ikke skete. ${ }^{19}$ Skoleudvalget foreslog, at der blev nedsat et udvalg til at gennemgå læreransøgningerne bestående af to seminarieforstandere, en repræsentant for friskolen, en for gymnasieskolerne, en for realskolerne samt formanden for Danmarks Lærerforening. Dette udvalg skulle udarbejde en liste over egnede mænd og kvinder, som Skoleudvalget derefter kunne henvise til, når skoler i Sønderjylland havde brug for lærere fra Danmark. ${ }^{20}$

Det Sønderjyske Ministerium kunne ikke støtte forslaget om et udvalg til behandling af kongerigske ansøgninger. Det var ikke rimeligt at holde Det Sønderjyske Ministerium og Undervisningsministeriet udenfor. Begge steder lå der allerede en række ansøgninger, der var sendt direkte hertil. ${ }^{21}$ Af Det Sønderjyske Ministeriums interne overvejelser fremgår det, at man havde tanker om at foreslå udvalget suppleret med repræsentanter for de to ministerier, ligesom man overvejede, om man allerede nu skulle udpege midlertidige amtsskolekonsulenter til at medvirke ved de midlertidige ansættelser. En henvendelse fra den sønderjyske lærerforening (se senere) havde dog fået ministeriet til at være mere tilbageholdende med at få danske lærere sendt til Sønderjylland i større tal allerede nu.

Ved et møde i Undervisningsministeriet den 17. september 1919 blev den fremtidige praksis indtil Genforeningen lagt fast. I mødet deltog bl.a. undervisningsminister S. Keiser-Nielsen, minister H.P. Hanssen, to repræsentanter for Skoleudvalget (Jefsen Christensen og Anders Lebeck) og en repræsentant for de tysktalende egne i Mellemslesvig (redaktør Ernst Christiansen, Flensborg), undervisningsinspektørerne, to seminarieforstandere samt repræsentanter for lærerforeningerne. ${ }^{22}$ Resultatet af mødet blev, at man fastslog som princip, at alle stillinger i det sønderjyske skolevæsen skulle slås regulært op, når der efter Genforeningen var blevet oprettet skoletilsynsmyndigheder, der kunne besætte embederne, dvs. skolekommissioner og skoledirektioner, hvor lokale myndigheder havde udnævnelsen, og Undervisningsministeriet, hvor det drejede sig om statslige embeder.

Endvidere påtog Skoleudvalget ved Jefsen Christensen sig at oprette et kontor, der kunne medvirke ved fremskaffelsen af lærerkræfter, indtil embederne kunne slås op på normal måde. Derfor tilstillede Det Sønderjyske Ministerium med mellemrum Skoleudvalget fortegnelser over modtagne ansøgninger og originale ansøgninger, efter at der omhyggeligt var taget maskinskrevne afskrifter af dem. Jefsen Christensen sørgede derefter i samarbejde med Jacob Appel $^{23}$ for, at skoler, der manglede lærere, kunne få kontakt med egnede folk. Jefsen Christensen og Det Sønderjyske Ministerium var ikke helt enige, om de sønderjyske skoler generelt skulle forsøge at få så mange lærere fra Danmark 


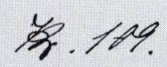

Da der ved den forelabige og fremtidige Fremskaffelse af Lærekræfter fra Danmark til Sønderiplland er opretlet et centralt Hiælpested her hos mig, med Undervisnings- og Sønderiydsk Ministeriums Billigelse og Tilslutning, og jeg i den Anledning har hele Tilbudsmaterialet fra Lærekræfter i Danmark, er det nødvendigt at jeg gennem Skoleforeningens Tillidsmand holdes paa det løbende med alt huad der sker i Sognene paa det Omraade.

De bedes derfor omgaaende besvare følgende Spørgsmaal:

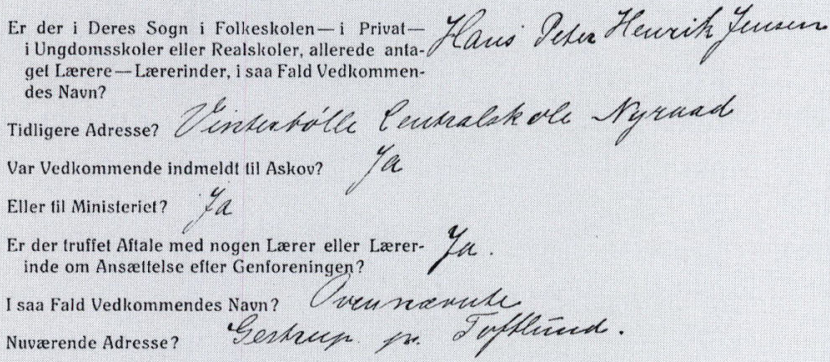

Har man Ønske om en bestemt Larer eller Lærerinde efter Genforeningen?

I saa Fald, Navn?

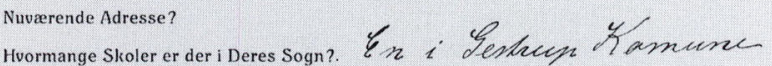
Hvilke er Byerne huori de ligger? Lestrey

For hvilken Skole har De givet Svar?

Huormange Klasser i huer Skole?

Hvilke Lærekræiter fra Danmark ønsker man i

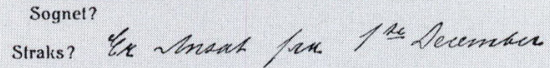

Efter Genforeningen?

Skal nogen af Lærerne forrette Kirkesang og Orgelspil?

Ønsker man Lærere af en bestemt kirkelig Retning? Er der gode Boligforhold for Larerne?

Er Skolebygningerne i forsuarlig Stand?

Vil De herefter ogsaa straks meddele mig naar der til en af Sognets Skoler er antaget en Larer eller Lærerinde, og saa Vedkommendes fulde Naun?

Tidligere Stilling og Adresse?

$$
\begin{aligned}
& \text { H. J. Christensen, } \\
& \text { Hegsbro. } \\
& \text { Yhidding }
\end{aligned}
$$

Modet $i$ Undervisningsministeriet i september 1919 forte til, at skoleudvalget ved Jefsen Christensen oprettede et kontor, der kunne hjalpe sonderjyske skoler med at få de rette larere fra Danmark. Det her gengivne skema blev benyttet til at skaffe oplysninger om behovet for larere i de enkelte sogne. Jefsen Christensens privatarkiv, pk. 22. LAA. 
Gårdejer Hans Jefsen Christensen, Hogsbro ved Hviding (18801956) var den helt centrale person for skolevasenet i Sonderjylland $i$ overgangstiden 1919-20. Han var både formand for Sonderjysk Skoleforening og for Valgerforeningens skoleudvalg. Efter Genforeningen var han i 27 år landstingsmedlem for partiet Venstre. Foto: Institut for sonderjysk Lokalhistorie.

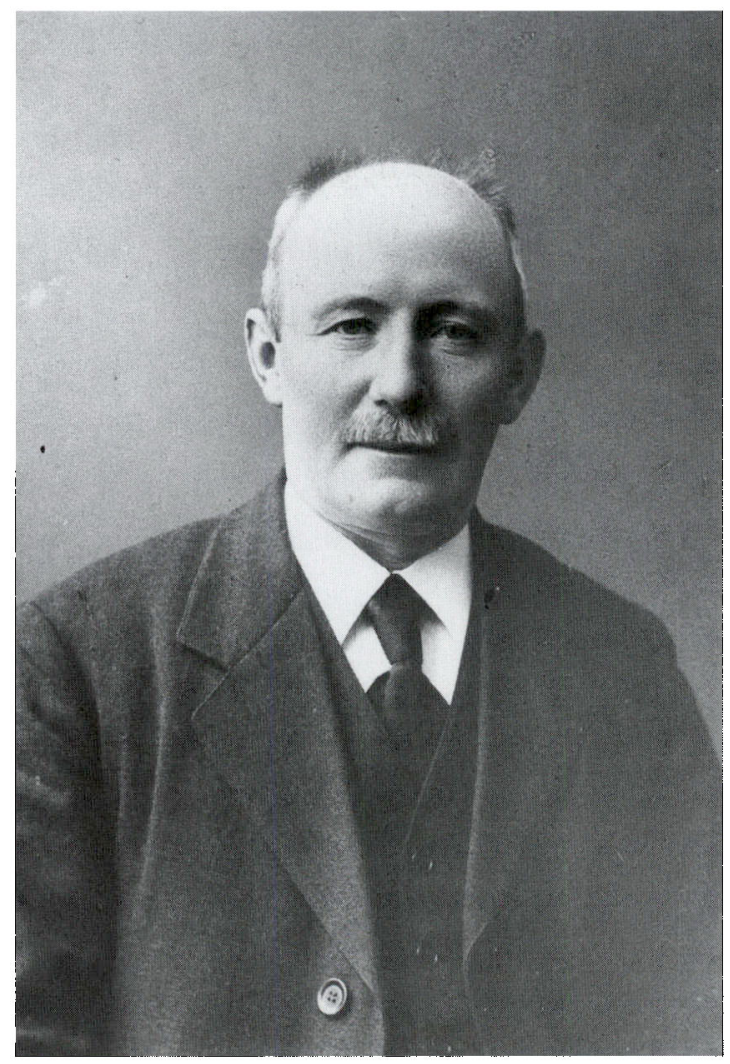

som muligt $\mathrm{i}$ en fart. H.P. Hanssen advarede $\mathrm{i}$ et brev den 22. oktober Jefsen Christensen imod at gå for hurtigt til værks, da de nuværende skolemyndigheder ikke kunne siges at have nogen kompetence til at bestemme, om de nuværende lærere skulle fjernes fra deres kald eller ikke. ${ }^{24}$ Jefsen Christensen måtte derefter $\mathrm{i}$ »Folkeskolen « dementere sine tidligere udtalelser, hvilket han gjorde med den begrundelse, at tidspunktet for afstemningen nærmede sig hurtigere, end han tidligere havde troet. ${ }^{25}$ Til gengæld måtte H.P. Hanssen lade sig belære om, at ministeriet tog fejl, når det gang på gang stilede sin korrespondance med Jefsen Christensen til »Skoleforeningen«. Det var Vælgerforeningens Skoleudvalg, der havde med lærerforholdene i overgangstiden at gøre, og det var til formanden herfor (det var også Jefsen Christensen!), ministeriet skulle henvende sig. ${ }^{26}$

Det Sønderjyske Ministerium var således et ekspeditionskontor for læreransøgningerne, som skulle videre til henholdsvis Jefsen Christensen og Undervis- 
ningsministeriet, men ministeriet havde dog en række muligheder for at gøre sin indflydelse galdende.

\section{Hvem søgte hvad, og hvorfor?}

I løbet af ministeriets levetid måtte det tage stilling til ca. 200 uopfordrede ansøgninger om ansættelse i skolevæsenet i Sønderjylland. Nogle indsendte ansøgninger flere gange, andre rykkede for svar på breve indsendt til Statsministeriets Slesvigske Udvalg i 1918-19. ${ }^{27}$

Det var en særdeles broget skare, der henvendte sig til Det Sønderjyske Ministerium. Aldersmæssigt var der en spredning fra folk, der havde forladt eksamensbordet for kort tid siden, til folk, der havde et langt arbejdsliv bag sig i skolen. De ældste var født før 1864, hvilket i nogle tilfælde lettede ansættelsen, da de, der var født i Slesvig før 1864, ifølge fredstraktaten uden videre var danske statsborgere ${ }^{28}$. Nogle af de ældste ansøgere pegede på vigtigheden af, at man ikke kun ansatte yngre kandidater, men at man supplerede lærerkorpset med mere erfarne folk. Dette synspunkt var der mærkeligt nok ingen af de yngre kandidater, der tænkte på!

De fleste ansøgere var allerede ansat i skolevæsenet. En stor del af dem var fra Danmark, lidt flere fra byen end fra landet. De mange byansatte søgte især overlærerstillinger, som blev slået op i februar 1920. ${ }^{29}$ Blandt ansøgerne i 1920 - ikke i 1919 - var der en del lærere, der allerede havde ansættelse i Sønderjylland, men som nu enten bad om at måtte beholde embedet eller opnå en forfremmelse. En tredje kategori var lærere, der var ansat syd for afstemningsområderne, enten i Holsten eller endnu længere sydpå i Tyskland.

En undersøgelse af ansøgernes uddannelsesmæssige baggrund viser, at der var en stor andel af seminarieuddannede. Der var omtrent lige mange fra kongerigske seminarier - hvoraf kun få var fra Jelling og Ribe, der ellers skulle fungere som grænseseminarier - og fra seminarierne i Tønder og Haderslev. Flere gjorde opmærksom på, at de havde frekventeret den danske afdeling $\mathrm{i}$ Tønder Seminarium. Kun enkelte havde læreruddannelse fra Ekernførde og Slesvig eller var uddannet længere sydpå.

Ud over de nævnte ansøgere fra folkeskolelærere var der et antal cand. mag.'er og teologer, der ønskede at blive ansat i gymnasier, på seminarier eller evt. i en større byskole. Heriblandt var der enkelte præster, der ønskede at skifte prædikestolen ud med katedret. Til gruppen af højere uddannede hørte også en dr.phil. i Hamborg, en direktør for en statslig handelsskole i Sachsen, en professor i kemi ved Universitet i Bremen samt en 29-årig med en italiensk erkendelsesteoretisk doktorgrad og med gode kundskaber i latin. 
Det altovervejende indtryk af de ansøgninger, der indkom til Det Sønderjyske Ministerium, var, at det var veluddannede og fastansatte folk, der søgte nye udfordringer i Sønderjylland. Men der var også en gruppe mennesker, der vejrede morgenluft, nu da så mange stillingsmuligheder åbnede sig på én gang. En lærer ved Landboskolen i Lyngby, der var bange for, at landbrugsfagene snart skulle tage al tid fra de almindelige skolefag og dermed gøre ham overflødig, en tidligere forstander for en højskole, der var blevet ødelagt af krigen, en frederiksbergsk lærer, der var blevet afskediget på grund af uenighed med skolens andre tysklærere, og som nu bl.a. ernærede sig ved at undervise ved Brasiliens ambassade, samt et par lærere, der var blevet afskediget på grund af nervøsitet og alkohol, var blandt dem, der nu meldte sig på arenaen.

Men der var også folk helt uden formel uddannelse. Blandt disse var en boghandler i Sorø, der havde opgivet at gennemføre en seminarieuddannelse, en tidligere friskolelærer, der nu bestyrede en tørvefabrik, og endelig som det mest udprægede eksempel, en landmand fra Fur. Han havde læst i Skive Folkeblad om lærermanglen og søgte derfor om at blive lærer eller regnelærer på Als. Som sine eneste kvalifikationer - udover, at han selv havde gået $\mathrm{i}$ en kommuneskole - fremhævede han, at han havde taget to små landbrugskurser, og at han hjemme havde "gennemregnet Becks Seminarieregnebog«. Han kom næppe i betragtning! Det gjorde næppe heller sønnen af en dansk seminarieforstander, som ikke på nogen måde satte sit lys under en skæppe. Skønt han ikke havde nogen færdiggjort uddannelse, mente han sig kompetent til at blive direktør for seminariet i Tønder, da han havde en onkel, der havde været tysk borgmester $\mathrm{i}$ byen, og da han i mange år havde hjulpet sin far med at bestyre »vort store hus«.

Hvad søgte folk så om? En del søgte bredt om ansættelse i skolevæsenet $\mathrm{i}$ Sønderjylland. Dette gjaldt næsten alle uuddannede og dem, der var uden ansættelse, da disse ikke var i en situation, der tillod dem at stille krav. Men der var også andre, der blot ville til Sønderjylland for at tage en nationalpolitisk opgave op.

Et stort flertal af dem, der specificerede deres ansøgning, ønskede ansættelse i byerne på østkysten. Der var flere grunde hertil. En del af lærerne fra Danmark ønskede samtidig en form for forfremmelse, og det mente de at få ved at søge til de større byembeder, nogle havde børn, der skulle i realskole, gymnasium eller seminarium, og her mente man, at mulighederne var bedst $\mathrm{i}$ østkystbyerne, selv om man skulle langt ind i 1920, før placeringerne af disse institutioner blev lagt fast. ${ }^{30} \mathrm{Da}$ overlærerembederne blev slået op først, tiltrak dette yderligere ansøgere til byerne, bl.a. fra en række ledere og lærere fra de pågældende skoler.

Til østkystbyerne hørte også Flensborg. Helt indtil afstemningen i 2. Zone i 


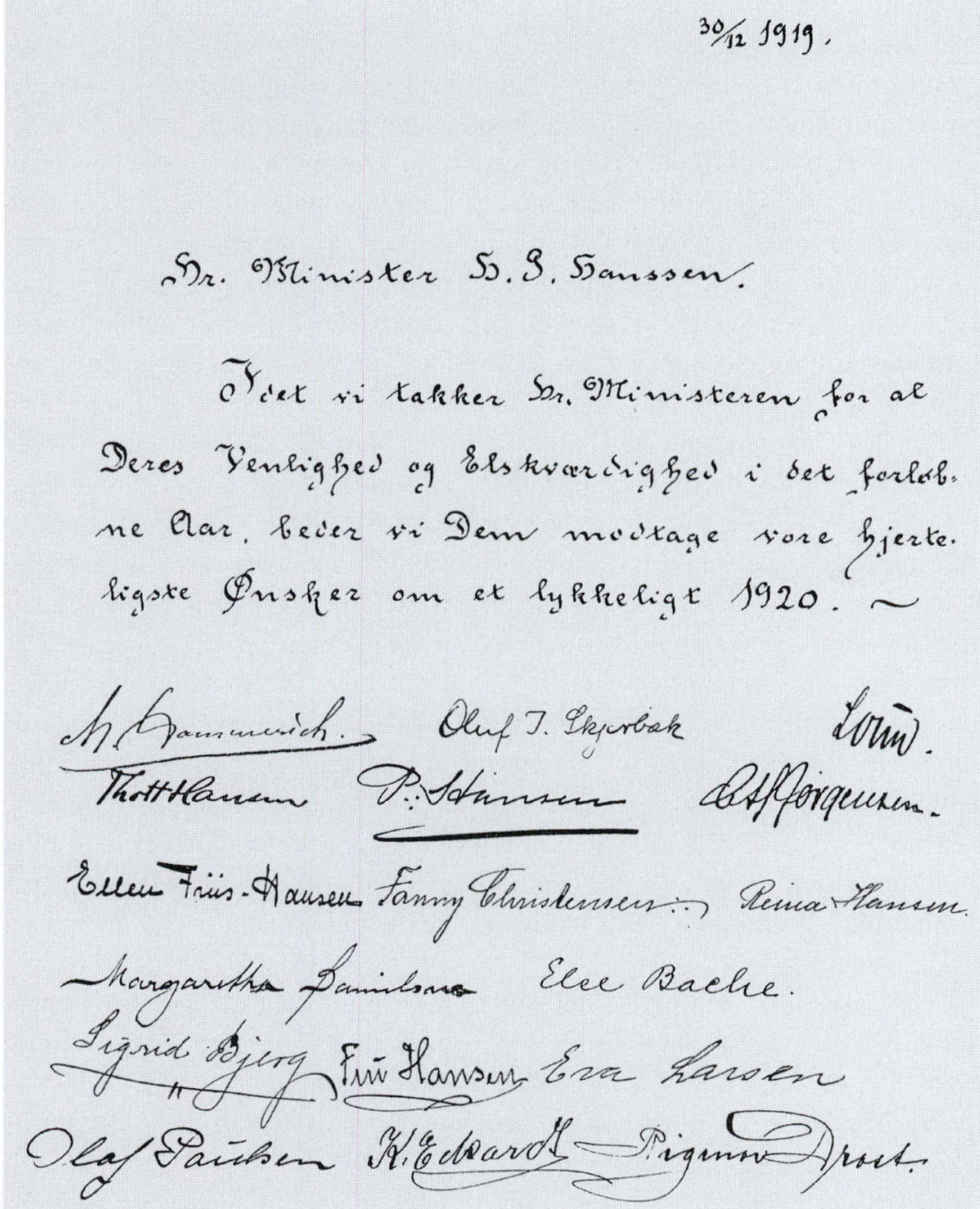

Det Sonderjyske Ministeriums personale omfattede mere end 20 personer, hvoraf de fleste var kontordamer. I alt sytten har undertegnet den nytårshilsen, som medarbejderne sendte ministeren i december 1919. H. P. Hanssens privatarkiv. LAA.

marts 1920 var der mange ansøgere, der ønskede at komme til Flensborg, enten som en af flere mulige byer, eller specifikt. Begrundelserne var bl.a., at man gerne ville gøre en indsats så langt sydpå som muligt, at de danske sprogkundskaber bedst slog til i et tysksproget område, eller som en lærerinde, 
der søgte embede i Flensborg eller omkring Flensborg Fjord, at hun gerne ville tilbage til sin fødeby.

Færre ville vestpå. Nogle søgte ansættelse ved seminariet i Tønder, som syntes at skulle fortsætte under nye vilkår, men generelt var der meget få, der utvetydigt ønskede stilling herude. Skoleforeningens formand, H. Jefsen Christensen, der selv boede i Høgsbro ved Hviding, beklagede, at for få søgte til midtlandet og vestkysten. Det var ønskeligt og nødvendigt, at kræfterne blev ligelig fordelt over hele landsdelen, og han tilkendegav, at eventuelle interesserede ikke ville blive skuffet hverken over "Børnematerialet" eller over befolkningen vestpå. ${ }^{31}$

\section{Nationalpolitisk opgave}

"Idet jo nu Dagen gryer for vor fælles store Sag, Genforeningen af vort sønderdelte Folk og Land, vil De maaske kunne forstaa, at det ikke er mig muligt længer at tilbagetrænge det hos mig længe nærede, inderlige Ønske om saa snart som muligt at kunne komme ned at være med i den store Glæde og det store Arbejde, der nu venter «. ${ }^{32}$

Så opstemt kunne en ansøgning stilet til minister H.P. Hanssen starte. Generelt blev der slået på de nationale strenge. Mange er virkelig opsat på at få lov til at ændre på 56 års preussisk skolepolitik i det nyvundne land. Der var efterhånden opstået en genforeningsstemning overalt i Danmark, og den kommer også til udtryk i mange af ansøgningerne. For dem, hvis fornemste formål med at søge til Sønderjylland var at få et bedre job, var de nationale begrundelser dog måske opfundet til lejligheden.

En skrev, at han altid havde haft interesse for Sønderjylland og haft bestemt tiltro til, at Genforeningen ville komme, en anden, at det var en hjertesag at deltage i det store og smukke arbejde i Sønderjylland, og endelig kunne en tredje ikke tænke sig nogen skønnere livsopgave end at være med til at tjene danskhedens erobring af det gamle danske land.

Enhver forbindelse til Sønderjylland blev trukket frem. Om det så var bekendtskab med sønderjyder på højskoleophold for 15 år siden, blev det anført. En præst anførte som begrundelse for at søge et skolejob syd for Kongeåen, at han havde haft embede tæt på grænsen $\mathrm{i}$ en del år. Temmelig mange var enten selv født i Nordslesvig eller havde forældre, bedsteforældre eller andre slægtninge, der var det. I flæng kan nævnes følgende eksempler: Stammer fra dansksindet familie (Claus Eskildsen); faderen angelbo, kæmpede på dansk side i 1864, blev degn i Bjolderup (Detlef Clausen); hustruens slægtninge bor i Sønderjylland; farbroderen havde været direktør for Flensborg Latin- og Realskole (Ove Hejde Simonsen); forældrene danske, moderen født i Uge 
(Louise Rützou); oldefaderen havde ejet Dybbøl Mølle, og bedstefaderen var født her (Helen Catherine Marie Hansen). Endelig henviste en kvindelig ansøger (Asta Bokkenheuser) til, at hendes far i 1864 havde måttet forlade en translatørstilling i Kiel, og at hun selv havde undervist i Dansk Vestindien og således var kendt med anderledes forhold.

En særlig gruppe ansøgere (ca. 12-15) ${ }^{33}$ mente, at de nu havde en særlig ret til at komme tilbage til hjemstavnen; det var dem, der var blevet eller havde følt sig fordrevet af de tyske skolemyndigheder. Et typisk eksempel på karriereforløb for disse lærere: Lærer D. Dirks nu ansat i Bargfeld i Holsten søgte om ansættelse i Sønderjylland. Han var født i 1864 i Flensborg af danske forældre, var uddannet ved Tønder Seminariums danske afdeling 1883-86, lærer i Skovby ved Haderslev 1886-1905 og i Harreslev ved Flensborg 1905-17. Derefter blev han tvunget til at flytte sydpå af nationale grunde, hvilket han fremlagde beviser på. Nu ville han som flere andre gerne hjem igen. Mellemskolelærer Jacob Knud Madsen i Rendsborg ønskede en hurtig afklaring, så han kunne slippe for at aflægge ed på den nye tyske forfatning. Et par sønderjyske lærere følte sig tvunget til at flytte sydpå, efter at de havde stemt dansk. En lærerinde (Cathrine Kylling), der i en årrække havde været ansat i Hjordkær, fik også valget mellem afsked og tvangsforflytning. Hun valgte så at tage til Danmark, hvor hun efter at have taget tillægseksamen i dansk blev lærerinde i Lemvig. Også hun ønskede at komme tilbage.

Et problem for ikke-kongerigske ansøgere var at bevise, at de havde optrådt positivt på den danske side eller i det mindste neutralt i nationalitetskampen. For de sønderjyske lærere havde ikke kunnet spille med åbne kort, så det kunne være vanskeligt i alle tilfælde at afgøre, på hvilken side lærerne inderst inde havde stået. Den senere så kendte danske frontfigur i mellemkrigstidens nationalitetskamp, Claus Eskildsen (1881-1947), skildrede i sin ansøgning om en stilling ved seminariet i Tønder de vanskeligheder, aktive folk havde. Eskildsen stammede fra en dansksindet familie. Han havde i 1901 taget eksamen fra seminariet i Ekernførde, da han som dansksindet ikke ville til Haderslev og Tønder. 1902-05 var han lærer i Sæd ved Tønder, 1905 blev han lærer ved Præparandskolen i Tønder, fra 1909 lærer ved seminariet sammesteds.

Om sin nationale stillingtagen skrev han bl.a.: »Jeg maatte som dansksindet Mand i mange Aar arbejde svært for at finde mig til Rette i Embedsstanden. I Sæd blev jeg kaldt dansksindet, og i Tønder By har man indtil det sidste "mistænkt« mig for det samme. Jeg søgte af Pligtfølelse at afskære Forbindelserne nordpaa og knytte nye med den tyske Kultur, og det lykkedes mig tilsidst saa vidt, at jeg kunde arbejde positivt med ved Folkeoplysning, Legemsog Ungdomspleje, men aldrig har jeg derved indtaget Kampstilling til Sønderjyllands Danskhed. Jeg havde som Gymnastiklærer i flere Aar den tekniske 
De dansksindede larere måtte for 1920 skjule deres sindelag eller som seminarielarer Claus Eskildsen lagge en kraftig damper på det. Claus Eskildsen måtte også deltage $i$ Verdenskrigen. Billedet af ham $i$ tysk uniform findes $i$ Institut for sonderjysk lokalhistorie.

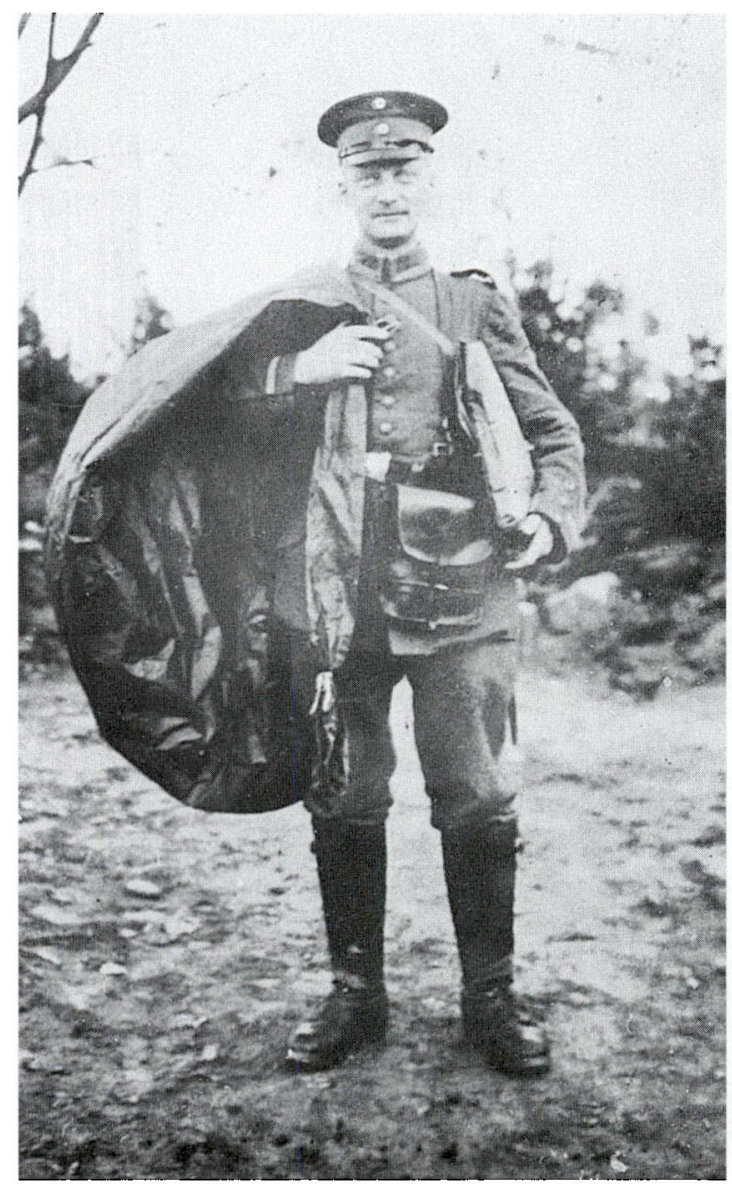

Ledelse af Legene paa Knivsbjerget, men har altid holdt mig fjernet fra Talerstolen og de patriotiske Foranstaltninger der og udviklede den Gang aabent som mit Ønske, at Danske og Tyskere en Gang fandt sammen i ideal Pleje af Ungdomslegene.«

Senere arbejdede han for, at hans hjemstavn skulle komme til Danmark. Han sad ti år som borgerrepræsentant i Tønder byråd, indtil han blev vraget, fordi han nægtede at underskrive en protestresolution imod byens indlemmelse i Danmark. Han skrev også en række oplysende tysksprogede artikler i "Tondernsche Zeitung « om nationalitetskampen og gik som tyskkyndig ind i det danske arbejde i 2.Zone. Han var derfor nu ganske kompromitteret i tyske kredse. Afsluttende gjorde Eskildsen opmærksom på, at han under normale forhold ville være blevet forfremmet til seminarieoverlærer, og at han i øvrigt 


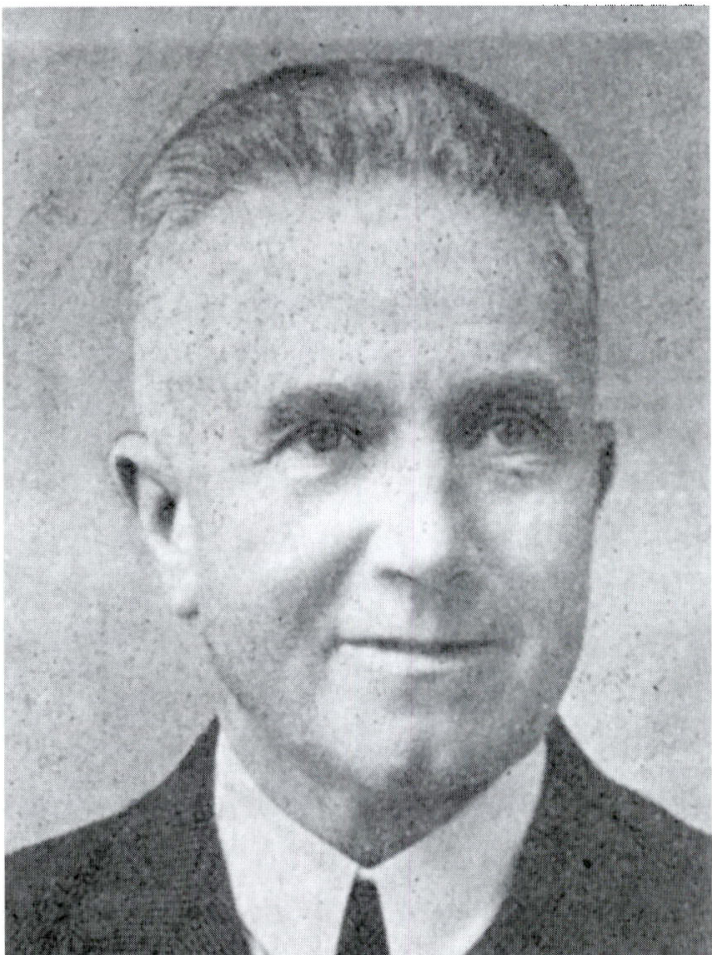

P. A.C. Wallentin (1873-1947), rektor ved pigemellemskolen $i$ Aabenraa, var en af de tyske skoleledere, der frygtede for sin stilling efter Genforeningen, og han henvendte sig derfor til Det Sonderjyske Ministerium for at hore om sine muligheder for at blive ved byens skolevasen. $D a$ der efter 1920 oprettedes en tysksproget afdeling af kommuneskolen $i$ Aabenraa, fik han sin ansattelse derr. Foto gengivet efter Deutscher Volkskalender Nordschleswig 1947 s. 90.

havde afslået en stilling som overlærer ved "Landesturnanstalt « i Spandau. Underforstået: de danske myndigheder burde nu sørge tilsvarende for ham. ${ }^{34}$

\section{Dansk og tysk sprogkyndighed}

Der kom også ansøgninger fra tysksprogede og tysksindede. Nogle søgte at skjule forholdet, så godt det kunne lade sig gøre. De nøjedes med at gøre opmærksom på de mindre gode danskkundskaber. Sindelaget var det bedst at tie stille med, nu hvor modparten skulle bestemme. Men der var undtagelser. Rektor P.A.C. Wallentin fra pigemellemskolen i Aabenraa spurgte Det Sønderjyske Ministerium om mulighederne for, at han kunne beholde stillingen i sin fødeby. Han indrømmede, at han ikke var det danske sprog helt mægtig, da han ikke havde undervist i det siden 1906 og i det hele taget ikke havde talt sproget siden. Desuden lagde han ikke skjul på, at han som følge af sin opdragelse var af tysk sindelag, men han lovede det fremtidige skoletilsyn, at han nationalt set ville optræde loyalt i embedet, hvis han fik lov til at beholde det. ${ }^{35}$ 
Rektor Wallentin ville desuden prøve at indhente de forsømte danskkundskaber i overgangstiden. Men for andre var dette ikke muligt. En mor til en yngre lærerinde, uddannet $\mathrm{i}$ Aachen, søgte på datterens vegne stilling $\mathrm{i}$ Sønderjylland. Moderen havde ganske vist talt dansk med datteren i barndommen, men denne havde nu glemt alle danskbrokker og kunne ikke undervise på dansk. For hende og andre uden de fornødne danskkundskaber var eneste chance for ansættelse de tysksprogede klasser, der ville blive oprettet.

Kendskabet til dansk sprog og kultur var i det hele taget et problem for de fleste lærere, der havde været ansat syd for Kongeåen. Flere af dem kunne måske nok tale dansk, men kun i den form, der i en ansøgning blev benævnt "folkedansk «, det vil sige sønderjysk. Desuden var kendskabet til dansk litteratur, historie og geografi ofte utilstrækkeligt, da disse emneområder havde været bandlyste i den sønderjyske skole før 1920 .

Der blev taget hånd om problemet. Undervisningsministeriet sørgede i samarbejde med Det Sønderjyske Ministerium og Statens Lærerhøjskole for, at en række sønderjyske lærere og lærerinder fik mulighed for at komme på et 6ugers kursus på Lærerhøjskolen. Den 15. september 1919 blev 72 lærere og 10 lærerinder modtaget på det første kursus, der omfattede både dansk sprog, litteratur og historie samt statsret og samfundskundskab. Fremtrædende kulturpersonligheder holdt foredrag på kurset, bl.a. litteraturprofessor Vilhelm Andersen, højskoleforstander Holger Begtrup, magister Georg Christensen, forstander Hans Olrik, kgl. skuespiller Peter Jerndorff m.fl. Sønderjyderne blev vist rundt på museer, besøgte skoler og andre institutioner, blev modtaget i festligt lag i Pædagogisk Selskab og i Det Sønderjyske Ministerium og fik lejlighed til at besøge Den store Skolekommission. Både gæster og værter var opfyldt af en euforisk stemning under hele kurset. ${ }^{36}$

Imidlertid blev kurset afbrudt før tiden. Sønderjyderne havde ganske vist fået de tyske skolemyndigheders tilladelse til at rejse, men snart fik det preussiske kultusministerium kolde fødder. Man ønskede ikke, at kursisternes embeder skulle stå ubesat i længere tid, og slet ikke, at de i mellemtiden blev varetaget af tilrejsende danske lærere. De sønderjyske lærere fik ordre til at tage hjem efter 4 uger, for ellers ville de blive afskediget. Efter nærmere overvejelse besluttede lærerne sig til at efterkomme kravet. Det efterfølgende planlagte kursus, som skulle have fundet sted i november-december, da det første kursus hurtigt blev overtegnet, blev aflyst. Først efter afstemningen i februar 1920 blev det afbrudte kursus genoptaget. ${ }^{37}$ Seminarieeleverne i Haderslev og Tønder, som var vordende sønderjyske lærere, fik en mulighed for at efteruddanne sig på de nærmeste seminarier i Kongeriget, Jelling og Ribe. Allerede i maj 1919 fik 32 seminarieelever på denne måde undervisning i dansk, historie, geografi og naturhistorie i Jelling. ${ }^{38}$ 
lærerinde, der kun talte »rigsmål«, noget bekymret for, hvordan hun skulle begå sig blandt sønderjysk talende.

Den afgørende forskel mellem de to kategorier af ansøgere var, at man sendte de sønderjyske lærere på kursus i Danmark, men man sendte ikke de danske lærere på kursus i Sønderjylland, selv om der sikkert var mange, der kunne have brug for det.

\section{Om at indynde sig}

Et generelt træk ved ansøgerbunkerne i Det Sønderjyske Ministerium var, at folk forsøgte at udnytte enhver lille forbindelse til særligt at bringe sig i betragtning. I enkelte tilfælde søgte de pågældende ikke selv, men lod deres far, mor, bror eller en person, som havde kendskab til en af de fremtrædende folk i forvaltningen, søge for dem. En rektor i Kiel, der flere gange havde skrevet direkte til H.P. Hanssen om at få en lederstilling i skolevæsenet i Sønderjylland, gjorde samtidig opmærksom på sine to lærerindedøtre. En cand. mag., der var lærer i St.Heddinge, lod sin bror i Øster Lindet søge for sig, da broderen havde haft mulighed for at tale med H.P. Hanssen.

En lang række ansøgninger blev stilet til H.P. Hanssen, eller de var ledsaget af et personligt brev til ministeren. Havde ansøgeren tidligere haft den mindste kontakt med ham, blev dette udnyttet. Ministeren måtte til stadighed modtage besøg, både når han var i København, og når han opholdt sig i Sønderjylland, af folk, der ønskede ansættelse. Og flere erklærede sig villige til at komme igen. Ofte måtte de dog gå forgæves, men så kunne kontorchef Hammerich og fuldmægtig Oluf Skjerbæk snakke med de audienssøgende. Ansøgere, der kendte Hammerich, kunne også skrive direkte til ham. En ansøger, der personligt kendte H.P. Hanssens broder, Chr. Hansen, Nørremølle, benyttede denne som mellemled.

Også andre folk, der var kendte enten i dansk politik eller i Sønderjylland, kunne optræde som mellemmænd eller som anbefalere. En frederiksbergsk lærer stilede således sin ansøgning til folketingsmand J.C.Christensen og henviste til deres forudgående samtale i Rigsdagen. Tilsvarende anmodede en anden ansøger venstrepolitikeren Klaus Berntsen om at forebringe ønsket om en passende stilling i Sønderjylland for H.P. Hanssen. Et tredje eksempel udgør et helt kinesisk æskesystem. En ansøgning fra en lærerinde ved Koed Skole og hendes forlovede indsendtes af en fattiginspektør i Horsens, der var lidt i familie med den forlovede, via landstingsmand K.K. Steincke, som han sikkert kendte fra socialvæsenet. Sluttelig sendte Steincke, der var medlem af Det Sønderjyske Udvalg, ansøgningen til kontorchef Hammerich. ${ }^{40}$ 
Forbindelsen til mellemmanden var i nogle tilfælde så perifer, at det kunne virke grinagtigt. En overlærer i Masnedsund sendte sin ansøgning via den sønderjyske politiker, gårdejer Peter Grau i Pøl, fordi han for tyve år siden havde været på ferie hos en svoger på Als og i den anledning havde besøgt P. Grau. Peter Grau sendte ansøgningen til H.P. Hanssen med bemærkningen om, at han ganske flygtigt mindedes den pågældende, men at han ikke kendte noget til ham hverken som menneske eller som opdrager.

Flere aspiranter forsøgte at indynde sig hos ministeren ved at erklære sig enig med hans politik. Det mest udprægede eksempel fandtes i en ansøgning fra en lærer i Gentofte kommune, der ønskede, at H.P. Hanssen skulle hjælpe ham med at blive amtsskolekonsulent. Til gengæld ville ministeren få en mand helt efter sit eget hovede, for lærerens trosbekendelse var: "Jeg er "Hanssenmand «, holder Hejmdal, er radikal og Højskolemand « ${ }^{42}$ Læreren glemte vist at tage i betragtning, at det var så som så med H.P. Hanssens radikalisme, selv om han var medlem af det radikale ministerium. En anden ansøger håbede, at Hanssen ville fortsætte som minister efter valget, og en tredje åbenbarede, at han ikke var »Flensborg-mand «.

Det har utvivlsomt været besværligt for H.P. Hanssen at skulle modtage så mange skriftlige og personlige henvendelser fra lærere og være udsat for så mange former for pression. På den ene side har det været et forstyrrende element i en travl virksomhed, men på den anden side var det vigtigt, at det blev de rigtige lærere, der kom til at opbygge det nye skolevæsen efter Genforeningen. Imidlertid var der klare grænser for, hvor stor indflydelse den sønderjyske minister og hans embedsmænd havde på ansættelsespolitikken.

\section{Det Sønderjyske Ministeriums sagsbehandling}

De indkomne læreransøgninger blev i ministeriet gennemgået af fuldmægtig Oluf Skjerbæk, der i de fleste tilfælde skrev et notat om, hvad der burde ske med ansøgningen, om der skulle indhentes yderligere oplysninger, om sagen skulle henlægges eller sendes videre, om der var mere principielle aspekter i sagen m.m. Derefter blev sagen forelagt kontorchef Martin Hammerich og i særlige tilfælde også for ministeren.

Ministeriet foretog derefter en kvalitetsbedømmelse af ansøgerne. Ansøgerne fra Danmark blev som regel udelukkende bedømt ud fra det indsendte materiale; normalt blev der ikke indhentet yderligere udtalelser. Her måtte eksamensresultatet (ikke alle havde høje seminarieeksaminer) og de indsendte anbefalinger tale for sig selv. Men de kunne også være afslørende nok. En lærer fra Rødvig kunne ikke skrive videre godt dansk, og Skjerbæk har i an- 
Oluf Skjerbak (1885-1979) var assistent $i$ Undervisningsministeriet, indtil han $i 1919$ blev fuldmagtig $i$ Det Sonderjyske Ministerium. Han var sagsbehandler på de mange lareransogninger, der indkom til ministeriet. I 1923 blev han overinspektor ved opdragelseshjemmene og udforte $i$ flere årtier et kampearbejde for borneforsorgen. Foto: Det kgl.Biblioteks Billedsamling.

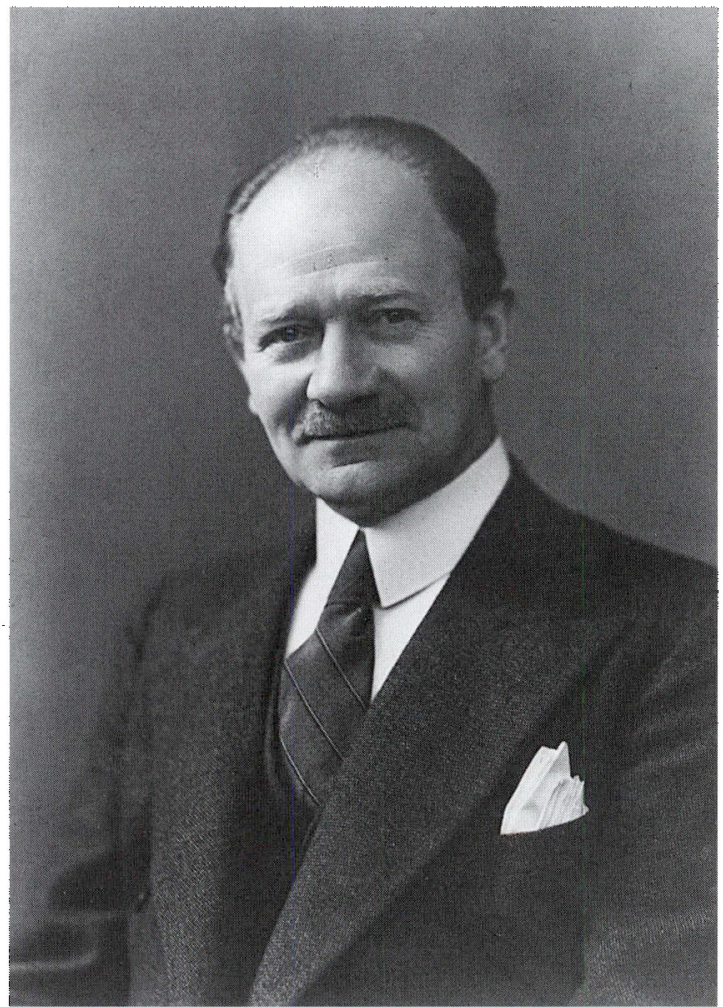

søgningen rettet stave- og sprogfejl med rødt! En lærer var ifølge en udtalelse "udpræget irreligiøs«, hvilket på den tid næppe var nogen anbefaling. ${ }^{43} \mathrm{I}$ et par tilfælde, hvor papirerne så meget tynde ud både med hensyn til uddannelse og lærererfaring, bad man ansøgerne give uddybende oplysninger, hvilket afslørede, at tavsheden skyldtes manglende kvalifikationer. Ministeriet gjorde efterfølgende over for Jefsen Christensen opmærksom på, at de pågældende lærere ikke havde undervist $\mathrm{i}$ årevis, hvilket utvivlsomt diskvalificerede dem i konkurrencen om stillingerne.

Ansøgninger fra sønderjyder og fra folk ansat længere nede i Tyskland blev gransket nøjere. Specielt var Ministeriet opmærksom på, om der var klare beviser for ansøgernes nationale loyalitetsforhold. I en del tilfælde hørte man de kontaktpersoner, som var opgivet i ansøgningerne, eller folk, der boede de steder, hvor ansøgerne var opvokset eller tidligere havde været lærere. Det sidste gjaldt især for lærere, der nu var ansat i Holsten og længere sydpå. ${ }^{44}$ I mange tilfælde bad Ministeriet Vælgerforeningens tillidsmænd de pågældende 


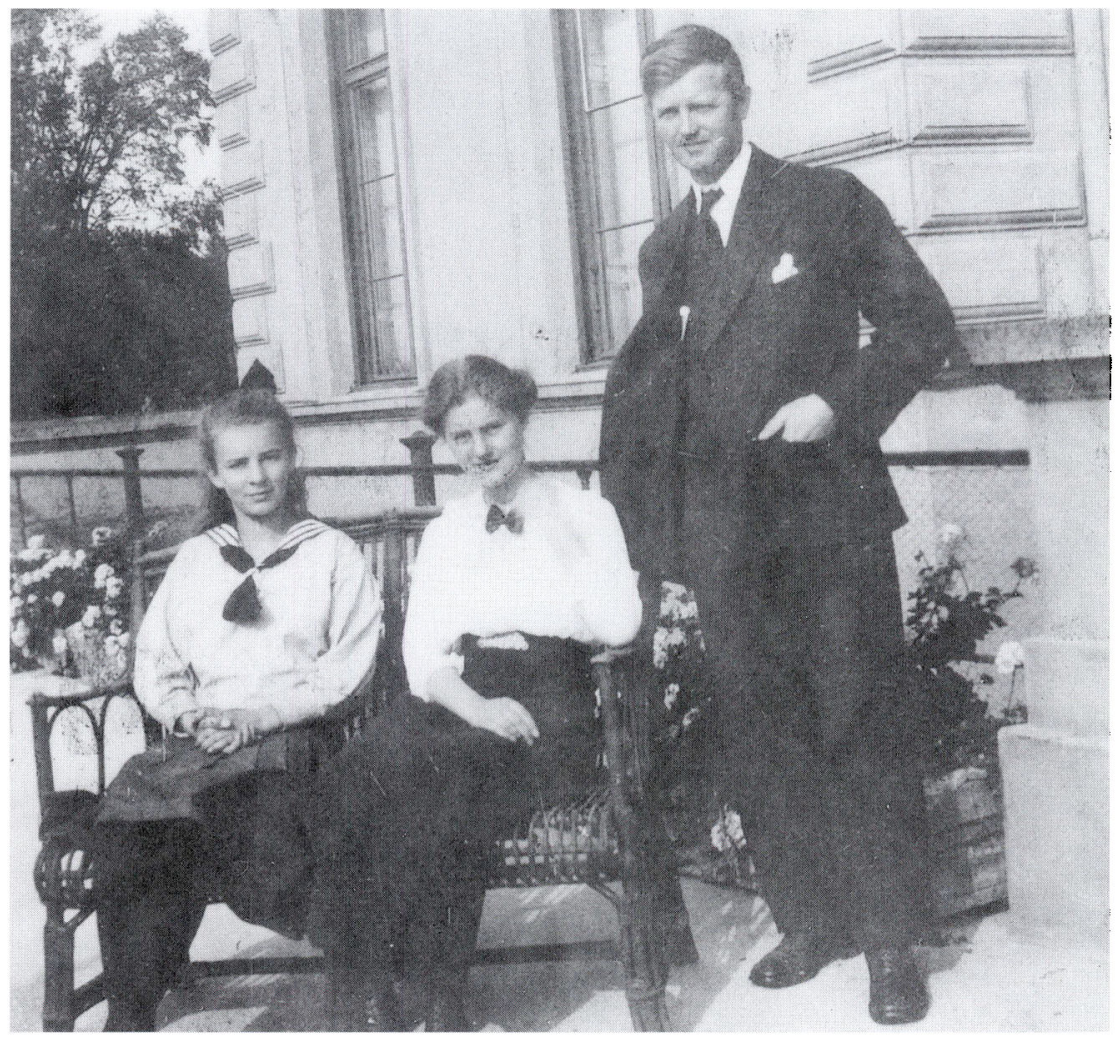

Martin Hammerich (1883-1940) var som kontorchef H.P. Hanssens narmeste medarbejder i Det Sanderjyske Ministerium. Det var af afgorende betydning, at de to arbejdede godt sammen, da ministeren ofte var fravarende på rejse $i$ Sonderjylland. Efter ministeriets nedlaggelse fortsatte Hammerich som kontorchef, forst $i$ Statsministeriets sonderjyske kontor og senere $i$ Udenrigsministeriets kontor for sonderjyske sager. I 1927 blev han direktor for Hypoteklånefondet. Fotografiet af Hammerich og to ukendte damer findes $i$ Institut for sonderjysk lokalhistorie.

steder om en udtalelse. På den måde fik ministeriet både positive og negative argumenter at viderebringe. F.eks. mente tillidsmand, gårdejer Jørgen Johansen, Bov Mark, at en mellemskolelærer i Rendsborg ved afstemningen den 10/2-1920 havde stemt dansk, og at hans familie var hæderlige og gode danske folk. Tilsvarende udtalte tillidsmand Chr.P. Todsen, Kværs, om en ansøger fra Bremen, der var født i Kværs, at både forældrene og den pågældende selv var udpræget dansksindede. Derimod udtalte købmand H. Fink, Aabenraa, at en kommunelærer i byen, der ønskede ansættelse ved realskolen, havde vist sig som en ivrig tysk ung mand, medens han gik på Præparandskolen, og derfor næppe var egnet til den pågældende ansættelse. 
I flere tilfælde blev den midlertidige borgmester Nicolaj Svendsen i Haderslev, der var medlem af Skoleudvalget, benyttet som kontaktmand. Han kunne dog ikke bruges, da han selv sendte en ansøgning til Det Sønderjyske Ministerium om en af amtsskolekonsulentstillingerne. I det tilfælde indhentede Ministeriet en meget positiv udtalelse fra forstanderen fra Statens Lærerhøjskole, Hans Olrik (Svendsen havde været på kursus her i 1898-99).

Svendsen var naturligvis kendt af ministeriets folk i forvejen, og det gjaldt også flere andre ansøgere. Det var dog ikke i alle tilfælde en fordel. Undervisningsministeriet havde sendt en ansøgning fra dr. Johannes Neuhaus til udtalelse i SØM (det kunne altså også forekomme). Fuldmægtig Skjerbæk kendte intet til vedkommende, men kunne henvise til, at ansøgerens afhandling om »Det nordslesvigske Spørgsmaal i Belysning af de nyeste forhistoriske Undersøgelser« havde fåt en alt andet end smigrende omtale af Gudmund Schütte i Grænsevagten..$^{45}$ Da H.P. Hanssen derefter fik forelagt ansøgningen, erklærede han, at »Dr. Neuhaus var umulig«.

På samme måde kunne der både komme noget positivt og negativt ud af at møde op i ministeriet eller at opsøge H.P. Hanssen på hans vej. I hvert fald opnåede de pågældende, at de ikke længere kun var navne på et stykke papir. For nogle var det klart en fordel: Om en lærerinde, der var ansat helt nede i Elsass, og som derfor på forhånd havde dårlige odds, hed det, efter at hun havde været en tur i København: "Andragerinden der personlig har været $\mathrm{i}$ Ministeriet anbefales paa det bedste«. Også andre, som personlig var ministeriets embedsmænd bekendt, fik positive ord med på vejen. Derimod bemærkede kontorchefen, efter at han havde haft besøg af en fhv. lærer fra Flensborg, der nu ville være amtsskolekonsulent: „Forekommer mig noget stortalende«.

I enkelte tilfælde gik ministeriet videre i sagsbehandlingen. F.eks. søgte en fynbo om at få embedet som gymnastikinspektør for landsbyskolerne i Sønderjylland. SøM forhørte sig da i Undervisningsministeriet og fik at vide, at den danske gymnastikinspektør ikke syntes, det var nogen god ide med en særlig sønderjysk gymnastikinspektør. Længst gik ministeriet på en forespørgsel fra Claus Eskildsen om hans fremtidsmuligheder. Efter at have forhørt sig i Undervisningsministeriet kunne Det Sønderjyske Ministerium fortælle Eskildsen, at der efter Genforeningen ville blive oprettet et statsseminarium med dansk undervisningssprog i Tønder, og man gav Undervisningsministeriet og konsulenten i sager vedrørende folkeskolen en orientering om Eskildsens ansøgning og om hans gode sproglige og nationalpolitiske forudsætninger for at overtage en post som seminarielærer i Tønder. 


\section{0 ansøgninger og ingen stillinger}

Efter gennemgangen af ansøgningerne sørgede Det Sønderjyske Ministerium for at give ansøgerne en slags svar. Standardsvaret til alle lød, at ministeriet ikke havde mulighed for at besætte stillinger. Ansøgerne skulle derfor være opmærksomme på opslag, når de til sin tid ville komme. Indtil de lokale danske skolemyndigheder var oprettet efter Genforeningen, kunne eventuelle ledige stillinger kun besættes midlertidigt. For stillinger inden for den højere undervisning var det Undervisningsministeriet, ansøgninger skulle stiles til. Men endnu i lang tid måtte SøM meddele ansøgere, at det endnu ikke var afgjort, hvilke institutioner der ville blive oprettet. Først meget sent i forløbet blev det endelig bestemt, at alle fire nordslesvigske byer fik et gymnasium. Folk, der især af sproglige grunde ønskede ansættelse et sted, hvor der oprettedes tysksprogede klasser, måtte væbne sig med tålmodighed, da grænsedragningen havde stor betydning for antallet. Da Flensborg ikke kom med, blev mulighederne for tysksprogede ansøgere væsentlig reduceret.

I en del tilfælde kunne ministeriet opfordre ansøgerne til, når de søgte igen, at skrive en fyldigere ansøgning, at den skulle være på dansk, ikke på tysk, at man nøjere burde fortælle, hvilken form for stilling man ønskede o.lign. Men som regel fik ansøgerne også at vide, at ministeriet ville sørge for at sende deres ansøgning ind til enten Skoleudvalget eller til Undervisningsministeriet. Kun i få tilfælde blev ansøgningerne ikke videresendt. Selv om ministeriet $\mathrm{i}$ visse tilfælde erklærede de pågældende for totalt uegnede, så blev de alligevel taget med på listerne til Skoleudvalget.

For at få overblik over ansøgningerne inddelte fuldmægtig Oluf Skjerbæk dem i 6 grupper. Med mellemrum indsendte han oversigter over ansøgningerne til henholdsvis Skoleudvalget og Undervisningsministeriet. En del af ansøgningerne blev sendt videre uden kommentarer, men i en del tilfælde tilføjede Det Sønderjyske Ministerium anbefalinger. Ofte skete det under henvisning til de medsendte eller yderligere indhentede anbefalinger. De anvendte adjektiver i ministeriets anbefalinger kunne gradbøjes. Anbefalingen kunne være almindelig, meget god, eller »den bedste anbefaling «, eller som det skete med rektor Carstensen ved drengeskolen i Haderslev takket være en anbefaling fra Nicolaj Svendsen, ministeriet skal »indtrængende« henstille, at ansøgningen tages under overvejelse ved besættelsen af posten som leder af den tyske folkeskoleafdeling i Haderslev.

Der var også forskel på, hvem der underskrev ministeriets svar til ansøgerne. Det normale var, at svaret var formuleret af Oluf Skjerbæk og underskrevet af kontorchef Hammerich og kontrasigneret af førstnævnte. Men der var en del tilfælde, hvor det var ministeren, der underskrev svaret sammen med Ham- 
merich eller Skjerbæk. Dette skete, hvor H.P. Hanssen kendte ansøgeren særdeles godt (det var altså ikke tilstrækkeligt, at ansøgeren havde skrevet til H.P. Hanssen). Men der var også forskel på folk. Når det drejede sig om fremtrædende personer, f.eks. præster, gymnasielærere, folk som Claus Eskildsen og Nicolaj Svendsen o.a. blev ministeren inddraget. ${ }^{46}$

Længere fremme i genforeningsprocessen blev ministeriets administration besværliggjort ved, at H.P. Hanssen opholdt sig meget i Sønderjylland. Sager kunne da blive forelagt ham på ministeriets kontor i Aabenraa, som blev ledet af Andreas Thulstrup. ${ }^{47}$ I enkelte af ansættelsessagerne blev ministeriets repræsentant J.H. Miang i Flensborg (ved den Internationale Kommission for Slesvig) også inddraget. ${ }^{48}$ I marts 1920 bestemte kontorchef Hammerich, at kontorerne i Aabenraa og Flensborg skulle have kopier af alle ministeriets afgørelser i sager, der var startet i de to regionalkontorer, samt af afgørelser i vigtigere principielle spørgsmål. Sager, som kontordamerne skulle afskrive til Aabenraa, skulle mærkes med blåt kryds og cirkel, og til Flensborg, rødt kryds og cirkel. ${ }^{49}$ Ministeriets administration var ikke blevet lettere.

\section{Skal alle sønderjyske lærere udvises?}

Ud over selve administrationen af læreransøgningerne måtte Det Sønderjyske Ministerium også tage stilling til en række mere generelle spørgsmål vedrørende lærerne. I en del af ansøgningerne satte lærere, der var fastansat i Danmark, som betingelse for at tage imod ansættelse syd for grænsen, at de fik en ordentlig løn, og at de ikke tabte deres anciennitets- og pensionsrettigheder. Ministeriet svarede, at løn- og pensionsforhold efter Genforeningen ville komme til at svare til de danske regler.

Derimod var der større problemer for de danske lærere, der tog til Sønderjylland i overgangstiden. På forespørgsel fra Jefsen Christensen måtte H.P. Hanssen fastslå, at hvor ønskeligt det end var, at der kunne skaffes danske lærere til at bestyre embederne midlertidigt, så kunne der ikke tilbydes dem mere $\mathrm{i}$ løn, end hvad de pågældende skolekommuner nu ydede i begyndelseslen; man kunne nemlig ikke forvente, at de højere preussiske skolemyndigheder ville anerkende sådanne ansættelser og yde tilskud til lærernes lønninger. ${ }^{50}$

Allerede inden dette svar var afgivet, havde ministeriet taget initiativ til at få aflønningsforholdet forbedret. En overlærer i Skjellebjerg på Sjælland havde henvendt sig til Det Sønderjyske Ministerium, da han havde fået at vide i Undervisningsministeriet, at han ikke kunne opretholde sin hidtidige løn og pension ved forflyttelse til en kommuneskole i Sønderjylland. ${ }^{51}$

SØM henvendte sig omgående til Undervisningsministeriet, da man lagde 
af elevtallet i klasserne, lærernes pligtige undervisningstimer, statsstøtte til udvidelse af skolebygninger m.v., til behandling hos de nyoprettede skolemyndigheder efter Genforeningen. ${ }^{54}$ Heller ikke spørgsmålet om tilsynsmyndighederne ville man indlade sig på. Det ville altsammen blive fastlagt i den foreløbige lov for folkeskolens ordning, som Skoleudvalget sammen med Rigsdagens sønderjyske udvalg arbejdede med. Loven blev vedtaget den 30 .juni 1920, men lovforslaget havde allerede i februar fået sin endelige skikkelse og indeholdt bl.a. en frisindet mindretalsordning inden for den offentlige skoles rammer. ${ }^{55}$

Derimod blev der flere gange offentligt fremsat forskellige rygter om skoleforholdene efter Genforeningen, som Det Sønderjyske Ministerium ikke kunne sidde overhørig. Feks. måtte H.P.Hanssen i juli 1919 dementere Wolffs Bureaus meddelelse om, at han skulle have udtalt, at alle embedsmænd inklusive lærerne ville blive udvist fra de områder, der ville blive afstået til Danmark. ${ }^{56}$ Senere på året blev samme historie gentaget i Schleswigsche Grenzpost, og ministeriet måtte atter rykke ud med et dementi. Det var en ganske grundløs beskyldning. I alle tilfælde, hvor befolkningen ønskede at beholde en lærer, ville ingen højere dansk myndighed skride ind mod den pågældende, forsåvidt vedkommende $»$ kan antages loyalt at ville rette sig efter de forandrede Forhold og udfører sit Embede tilfredsstillende «. ${ }^{57}$ Også i ansøgninger kunne der optræde lignende rygter, at alle sønderjyske lærere skulle forflyttes længere op i Kongeriget, eller at alle førstelærerposter skulle besættes med danskere. ${ }^{58}$ Også nord for Kongeåen florerede hårdnakkede forlydender, f.eks. om at embedsbesættelserne i skolevæsenet i Sønderjylland blev foretaget "under Haanden «, eller at alle stillinger skulle besættes med lærere, der var født i Sønderjylland. ${ }^{59}$

Det Sønderjyske Ministerium nåede efterhånden frem til en politik i det vigtige spørgsmål: danske lærere kontra sønderjyske lærere. ${ }^{60} \mathrm{I}$ den sammenhæng var de sønderjyske lærere, der var på kursus i København, en vigtig pressionsgruppe. Dels var selve deres tilstedeværelse med til at fortælle, at der var en stor gruppe nationalt indstillede lærere blandt de allerede ansatte, og dels dannede de under opholdet en Sønderjysk Lærerforening under ledelse af lærer Detlef Clausen, Dybbøl, som opstillede en række ønsker i lærerspørgsmålet. Blandt disse var, at de hidtil ansatte lærere, der ikke havde vist sig provokerende i politisk henseende skulle have lov til at blive, hvis befolkningen ønskede det, og at de ikke skulle søge deres egne embeder. ${ }^{61}$

Det Sønderjyske Ministerium var enige med de sønderjyske lærere i, at der i videst muligt omfang skulle tages hensyn til de nuværende lærere; de kunne blive $\mathrm{i}$ embedet, hvis befolkningen ønskede det, og de $\mathrm{i}$ det hele taget var $\mathrm{i}$ stand til at varetage deres stilling på forsvarlig måde, især med hensyn til undervisning i dansk. Derimod afviste ministeriet, at der kunne blive tale om umiddelbar ansættelse; alle embeder måtte slås op. 
Ministeriets bemærkninger i forbindelse med en række ansøgninger bekræfter denne holdning. Hvis en ansøger var født i Sønderjylland og/eller havde været lærer her, var loyal og i stand til sprogligt at klare sig, så overgik en sådan ansøger en tilsvarende fra Danmark. Det var afgørende, at der blandt det fremtidige lærerkorps var en stor del, der kendte til lokalbefolkningen og de særlige betingelser, skolevæsenet skulle virke under. Eller som det hed i en anbefaling for en sønderjysk lærer, at der blandt embedsstanden fandtes en flok, der havde winstinkt sammen med folket i snævrere forstand og som vil kunne virke vejledende over for kollegaer fra Kongeriget under mange forhold «. ${ }^{62}$

Det betød ikke, at alle lærere skulle beholdes. Folk, der var kommet sydfra, og lærere, der havde stillet sig illoyalt, skulle bort. H.P. Hanssen udtrykte retten hertil på følgende måde i et svar til den ovennævnte tysksindede rektor Wallentin i Aabenraa og i et tilsvarende svar til en anden rektor: det må ifølge både den danske og tyske retslære anses for galdende folkeret, "at den Stat, der erhverver et hidtil til en anden Stat hørende Territorium, ikke har nogen Forpligtelse til at tage de Embedsmænd, der ved Afstaaelsen er ansat paa Territoriet, i sin Tjeneste. Det maa derfor ogsaa antages, at Afstaaelsen af en Del af Sønderjylland til Danmark vil medføre, at de i de paagældende Distrikter tjenstgørende Embedsmænd i Kraft af selve Afstaaelsen maa betragtes som afskedigede ${ }^{63}$

\section{Ministeriets afvikling og betydning}

Det Sønderjyske Ministerium kom ikke til at opleve, at de mange stillinger inden for skolevæsenet blev besat. Kun overlærer- og amtsskolekonsulentembederne blev slået op, før H.P. Hanssen måtte gå af som minister. Det er lidt vanskeligt at sætte en bestemt dato som punktum for Det Midlertidige Sønderjyske Ministerium. Af H.P. Hanssens dagbøger fremgår det, at hans arbejde for regeringen ikke ophørte ganske med ministeriet Zahles afgang den 29. marts 1920. Han deltog i de fleste ministermøder i ministeriet M.P. Friis's levetid, og han modtog et honorar på $2000 \mathrm{kr}$. for april måneds arbejde som regeringens rådgiver. ${ }^{64}$

Det praktiske arbejde i Det Sønderjyske Ministerium fortsatte, selv om kontorchef Hammerich udtalte, at han kun ville tage imod ordre fra H.P. Hanssen. ${ }^{65}$ Ved kgl. resolution af 9/4-1920 (bek. 12/4-1920) blev ministeriets opgaver henlagt til Statsministeriet. Ministeriets embedsmænd med Martin Hammerich og Oluf Skjerbæk i spidsen fortsatte deres arbejde, men nu som et kontor under Statsministeriet. Også kontorerne i Aabenraa og 


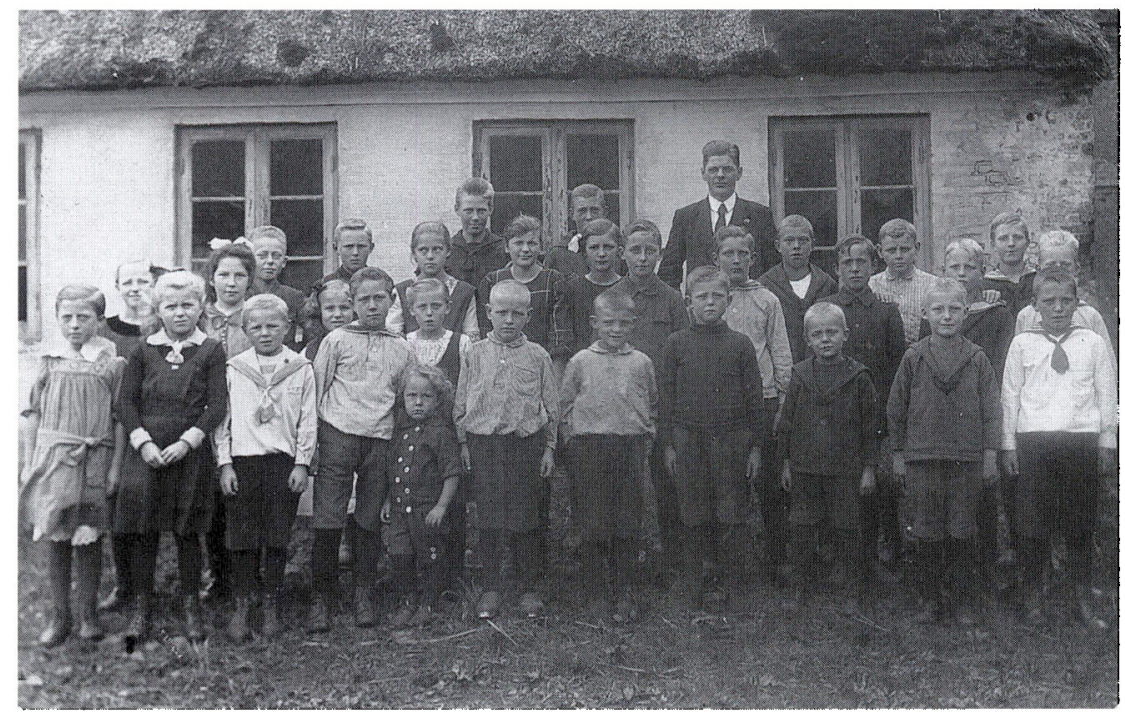

Hojrup Skole $i$ Stepping sogn var en af de mange skoler, der fik ny larer i 1920. Jorgen Holger Skovrup er fotograferet med en klasse foran skolen kort tid efter sin ansattelse. Han havde larereksamen fra Gedved Seminarium i 1918. Foto: Institut for sonderjysk Lokalhistorie.

tør for opdragelseshjemmene, kan man sige, at Det Sønderjyske Ministerium administrativt set var et afsluttet kapitel.

Skal man på baggrund af behandlingen af læreransøgningerne give en vurdering af H.P. Hanssens ministeriums betydning, må det blive et både og. Når det gælder konkrete afgørelser, havde ministeriet ingen indflydelse. Det havde ingen magt til at ansætte folk eller til at træffe beslutninger i vigtige spørgsmål. På den måde var H.P. Hanssen $\mathrm{i}$ en anden situation end fagministrene. Han var, som der også stod i den kgl. resolution, som udnævnte ham i juni 1919, "Minister uden Portefeuille«.

På den anden side var den manglende "ressort « også en styrke. Han kunne blande sig i samtlige ministeriers område, når det drejede sig om spørgsmål vedrørende Sønderjylland og områdets forhold efter Genforeningen. På skoleområdet var ministeriet et vigtigt kontaktled mellem Vælgerforeningens Skoleudvalg og det danske Undervisningsministerium. For mange lærere både syd og nord for Kongeåen var det meget vanskeligt at få et overblik over fremtidens administrative myndigheder, hvem der skulle besatte hvilke embeder. Blandt andet fordi dette først blev lagt fast langt fremme i genforeningsprocessen. De sønderjyske skolekommissioner og amtsskolekonsulenter var endnu ikke i funktion. Da var det af betydning, at der var et sønderjysk ministerium, man kunne henvende sig til. 
De mange læreres henvendelser til H.P.Hanssen fortæller om ministerens personlige indflydelse på genforeningsprocessen. Han var kendt viden om, hvilket havde stor betydning for hans ministerium. Hertil bidrog endvidere, at kontorchef Martin Hammerich også havde mange forbindelser til Sønderjylland, og at han arbejdede godt sammen med H.P. Hanssen. De politiske skærmydsler omkring H.P. Hanssens udnævnelse og konsekvenserne heraf i Sønderjylland var derimod med til at svække ministeriet.

Undersøgelsen af ministeriets forvaltning af læreransøgningerne viser, at det var dets politik at hindre, at uegnede lærere fra Danmark overtog et stort antal af lærerstillingerne. Med hensyn til de hidtidige sønderjyske lærere ønskede ministeriet så mange af dem genansat som muligt, men betingelsen var, at de var loyale. Det var ganske vist befolkningens egen sag at afgøre dette spørgsmål, men Det Sønderjyske Ministerium gjorde sit for at undersøge, om det var tilfældet. Det Sønderjyske Ministerium var med sin forberedende, vurderende rolle med til at skaffe det rette beslutningsgrundlag for de egentlige embedsbesættelser, som skolekommissioner/amtsskolekonsulenter og Undervisningsministeriet foretog i sommeren 1920. Det Midlertidige Ministerium for Sønderjyske Anliggender bidrog således til, at den sønderjyske skole fik det bedst mulige lærerkorps efter 1920 , og det kan derfor konkluderes, at ministeriet var et vigtigt led i administrationen af skolevæsenet i overgangstiden mellem tysk og dansk skole.

\section{Anvendte forkortelser i noterne}

$\mathrm{S} \varnothing \mathrm{M}=$ Det Midlertidige Ministerium for Sønderjyske Anliggender

$\mathrm{UM}=$ Undervisningsministeriet

ans. =ansøgning

LAÅ = Landsarkivet for Sønderjylland, Aabenraa

H.P. H. $=$ H.P. Hanssen

Det anvendte arkivmateriale findes, når andet ikke anføres, i Rigsarkivet.

NOTER

1. Det Midlertidige Ministerium for Sønderjyske Anliggender. Andragender om ansættelse 1919 20. Pakke I-IV. Ansøgningerne er journaliseret under nr. 901, 1001, $1101 \mathrm{og}$ 1901. Ansøgninger om stillinger i skolevæsenet er journaliseret under nr. $1001 \mathrm{og}$ fortløbende nummereret $\mathrm{i}$ to rækker for henholdsvis 1919 og 1920 . Fra 1919 findes desuden en lang række skolevæsensansøgninger i journalsag 77/1919.

2. L.S. Ravn: Træk af folkeskolens historie i Nordslesvig 1864-1920. Åbenrå 1981; L.S. Ravn: Danskuddannede folkeskolelærere i Nordslesvig under preussisk styre. 1966. 
3. Jfr. L.S. Ravn: Den mest omstridte begivenhed i Nordslesvigs skolehistorie. Sprogforordningen af 18. december 1888 (Årbog for dansk Skolehistorie $1968 \mathrm{s.} \mathrm{68-96).}$

4. Rigsarkivet og hjælpemidlerne til dets benyttelse. Red. Wilhelm von Rosen. II,4 s. 1888 (1991).

5. Om skoleudvalgets nedsættelse og virke se H. Jefsen Christensens redegørelse i Sønderjysk Skoleforening 1892-1942 Kolding $1942 \mathrm{~s}$. 136-78.

6. Ansøgning fra pastor C.K. (SØM J.sag 77/1919).

7. Se f.eks. J.H. Byriel: Folkeskolen i Sønderjylland ved Genforeningen (Folkeskolen 17/4-1919 s. 188-89); Kjeld Galster: De sønderjyske Gymnasieskoler (Gymnasieskolen marts 1919 s. 49-52).

8. Både ved skolemødet $\mathrm{i}$ Varde (2500-3000 deltagere) og i Odense (500 deltagere) i Pinsen talte biskop Koch, Ribe, om Sønderjylland; i Holbæk talte Jefsen Christensen om skoleforholdene i Sønderjylland og i Roskilde ved Sjællands stifts skolemøde talte prof. Vilh. Andersen om Sønderjylland i dansk digtning (se referaterne i Folkeskolen $1919 \mathrm{nr} .22,23$ og 26).

9. Jfr. Erik Nørr: Lokalsamfundenes kamp om seminariedriften 1791-1991 (i Adda Hilden og Erik Nørr: Dansk Læreruddannelse 1791-1991 bd. 3. Odense 1993 s. 305-89).

10. Niels Jul: Tilgangen til Seminarierne (Dansk Seminarieblad juni 1919 s. 99-101); Folkeskolen nr. 241918 s. 231 , nr. 261919 s. 312 og Kobstadskolen nr. 71919 s. 45.

11. Lærere til Sønderjylland (Folkeskolen 12/6-1919 s. 228); Hvilke Lærere vil til Sønderjylland? (Købstadskolen 15/6-1919 s. 42): I dagbladene fandtes opfordringen indrykket noget tidligere, f.eks. i Kristeligt Dagblad 5/6-1919.

12. Betænkning med Lovforslag afgivet af Skolekommissionen i Henhold til Lov nr. 77 af 21 . Februar 1919. Kbh. 1923 s. II.

13. Henvendelserne er bevaret i to pakker i Jacob Appels privatarkiv (LA $)$. Til de registrerede ans. skal lægges en del uregistrerede.

14. Lærere til Sønderjylland (Folkeskolen nr. 271919 s. 323).

15. Troels Fink: Da Sonderjylland blev delt 1918-1920. Aabenraa 1978. Bd. II s. 56-77.

16. Kgl. res. 24/6-1919 (bek. 30/6). Love og Anordn. 1919 s. 924, 935 og 1006.

17. Lov 30/6-1919 om Oprettelse af et midlertidigt Embede som Kontorchef under Minister uden Portefeuille H.P. Hanssen (Love og Anordn. 1919 s. 1011); Rigsdagstidende 1918/19 F sp. 6168$69,6225,6245 f$, L sp. 2432 .

18. SØM Journalsag 29/1919; Hof- og Stat 1920 sp. $399 f$.

19. SØM til Jacob Appel 10/7 og 30/7-1919; Jacob Appel til SØM 7/7 og 31/7-1919 (beror ligesom den følgende korrespondance i SøM J.sag 77/19).

20. Jefsen Christensen til H.P. Hanssen 6/8 og 14/8-1919.

21. H.P. H. til Jefsen Christensen 11/8-1919; jfr. de interne overvejelser i SØM om sagen.

22. UM. 1. Dep. Journalsag AV2477/1919; se også mødeindkaldelserne i SØM J.sag 77/19.

23. Jfr. Nicolaj Svendsen: I Genforeningens Tjeneste. Sønderjydsk Skæbne. Bd. III Åbenrå $1968 \mathrm{~s}$. 41.

24. Jefsen Christensen til H.P.H. 24/9, 9/10 og 28/10-1919, H.P. H. til Jefsen C. 22/10-1919.

25. H. Jefsen Christensen: Lærermanglen i Sønderjylland (Folkeskolen 9/10-1919 s. 499 og 23/101919 s. 526-27).

26. Jefsen Christensen til SøM 16/11-1919.

27. Jfr. ansøgningerne i SøM. Det Sønderjyske Udvalg. J.sag 372/1919.

28. Jfr. ansøgning $24 / 20$.

29. Folkeskolen nr. 9 26/2-1920.

30. Jfr. UM 2. Dep. Journalsag 1284/1919 (H.P. H. udtalte sig i skr. 21/8-1919 til UM om den danske stats forhold til det højere skolevæsen i Sønderjylland).

31. H. Jefsen Christensen: Lærermanglen i Sønderjylland (Folkeskolen 23/10-1919 s. 526-27).

32. SØM J.sag 77/1919 B.

33. Eksempler: Ans. 47/1919, 2, 5, 7, 8, 24, 42, 45, 47, 54, 57, 59 og 64/1920; jfr. H.P. Hanssens udtalelse om, at der alene i 1911 var 40 nordslesvigske lærere, der flyttede sydpå (citeret i L.S. Ravn: Træk af folkeskolens historie i Nordslesvig 1864-1920. Åbenrå 1981 s. 190).

34. Ansøgning 23/1920, jfr. ogs̊̊ hans tidligere ans. 55/1919; se også Claus Eskildsen: »Hjemmetyskernes Smertensvej« (Grænsevagten 1937 s. 311-13), hvor han imødegik Vilh.la Cour og tyske 
blades antydning af, at han skulle have været hjemmetysker før Genforeningen. Cl.E. kom bl.a. ind på nogle af de samme forhold, som han allerede havde næunt i sine ansegninger i 1919-20.

35. Ansøgning $77 / 1919 \mathrm{nr}$. 24. Wallentin blev efter Genforeningen ansat som lærer ved den tysksprogede kommuneskole i Aabenraa; i 1932 blev han leder af skolen, hvilket ikke var efter hele det tyske mindretals ønske (Åbenrå Bys Historie. Red. J. Hvidtfeldt og P. K. Iversen. III (1974) s.17879); Dansk Skole-Stat. Red. N.A. Larsen. IV. Kbh. 1934 s. 76.

36. Om forberedelsen af kurset og kursets forløb se UM 1. Dep. Journalsag AV2210/1919. Udgifterne til kurset blev dækket via en tillægsbevilling til finansloven; se også Folkeskolen 1919 s. 409, 469, 487, 511-12; Hejmdal 13/9, 17/9, 10/10, 13/10 og 15/10-1919.

37. Folkeskolen 1919 s. $530,541,554,579,1920$ s. 183.

38. Dansk Seminarieblad feb. 1920 s. 12-13.

39. SøM Journalsag 113/1919 (ansøgninger om kursus på Statens Lærerhøjskole).

40. Ans. 2/1920; den pågældende havde henvist til, at han vanskeligt kunne få fri fra sin stilling $i$ Hamborg.

41. Ans. 33/1919 (ligger i J.sag 77/1919).

42. Ans. $32 / 1920$.

43. J.sag $77 / 1919 \mathrm{nr} .48$ og 3.

44. Med hensyn til lærerne, der var ansat i Sønderjylland, havde SøM de fornødne oplysninger: se således den samlede fortegnelse over de sønderjyske lærere med en bedømmelse af deres nationale optræden (SØM. Det Sønderjyske Udvalg. J.sag 430/1919) og Skoleudvalgets spørgeskemaer om lærerne, som i feb. 1919 blev sendt til Vælgerforeningens tillidsmænd. Disse skemaer findes i SøM. Statistisk Departement. Rets- og skolepersonale.

45. Bogen udkom i Jena i 1919 både i en dansk og en tysk udgave. Anmeldelsen findes i Grænsevagten 1919-20 s. 96-99.

46. Jfr. således Hammerichs påtegning i forbindelse med en ansøgning fra en præst (43/1919): „Bør vist underskrives af Ministeren«.

47. Se f.eks. Ansøgning 25/1920.

48. Se Ansøgning 57/1920 og 66/1920.

49. Se bilag vedlagt Ansøgning 46/1920.

50. H.P. H. til Jefsen Christensen 22/10-1919 (J.sag 77/19).

51. Ansøgning 30/1919.

52. SØM til Undervisningsministeriet 16/10-1919 og UM til SØM 1/9-1919 (Ansøgning 30/19).

53. SØM til Jefsen Christensen 28/11-1919 (J.sag 77/19); Folkeskolen 18/12-1919 s. 636.

54. Se bla. SØM's svar i Ansøgning 37 og 39/1919.

55. Lov 30/6-1920 om nogle Bestemmelser med Hensyn til en midlertidig Ordning af Folkeskolens Administration i de sønderjydske Landsdele; jfr. H. Jefsen Christensen i Sønderjydsk Skoleforening 1892-1942. Kolding 1942 s. 165-76.

56. Dementiet er offentliggjort i Hejmdal 25/7-1919.

57. SØM’s oplysningskontor sender 12/11-1919 avisudklip fra Schleswigsche Grenzpost 8/11-1919; SøM til Oplysningskontoret med dementi 24/11-1919 (J.sag 77/19).

58. Se Ansøgning 1/1919 og J.sag 77/19 nr. 40.

59. Ansøgning 4/1919 og 24/1919.

60. Også $\mathrm{i}$ den offentlige debat var spørgsmålet brændende. I Folkeskolen rasede der i en række numre en polemik rejst af J. Bundgaards indlæg: "Nu lærer vi Dansk paa Tysk«, hvori han slog til lyd for, at det størst mulige antal lærere i Sønderjylland skulle udskiftes (Folkeskolen nr. 11 1920 s. 140-41). Modindlæg og gensvar findes i nr. 12, 13, 14, 16 og 17.

61. Det sønderjyske lærerudvalgs ønsker dateret 2/8-1919 ligger i SøM J.sag 77/19 underskrevet af D. Clausen; udvalget havde den 23-24/7 været i København for at forhandle med H.P.H. og Danmarks Lærerforening (Folkeskolen 7/8-1919 s. 388); udvalget konstituerede sig som Sønderjydsk Lærerforening i slutningen af september (Folkeskolen 2/10-1919 s. 485-86).

62. Ansøgning 47/1919. Ordene er M.K.Grams, men de udtrykker godt holdningen i SøM. Jfr. f.eks. SøM's udtalelse i Ansøgning 6/20 (meget ønskeligt, at en af amtsskolekonsulenterne blev en sønderjyde). 
63. J.sag $77 / 19$ nr. 24 og nr. 43.

64. H.P. Hanssens dagbøger 29/3-14/4-1920 og 15/4-8/5-1920 (H.P. Hanssens privatarkiv LAÅ).

65. H.P. Hanssens dagbog 30/3-1920.

66. SØM Journal 29/1920 nr. 30 (opsigelsen ekspederedes gennem Statsministeriet 4/12-1920). Det sønderjyske kontor i Statsmin. blev nedlagt ved Kgl. resol. 24/11-1920. 